Prepared in cooperation with the Federal Emergency Management Agency

\title{
Tropical Storm Irene Flood of August 2011 in Northwestern Massachusetts
}
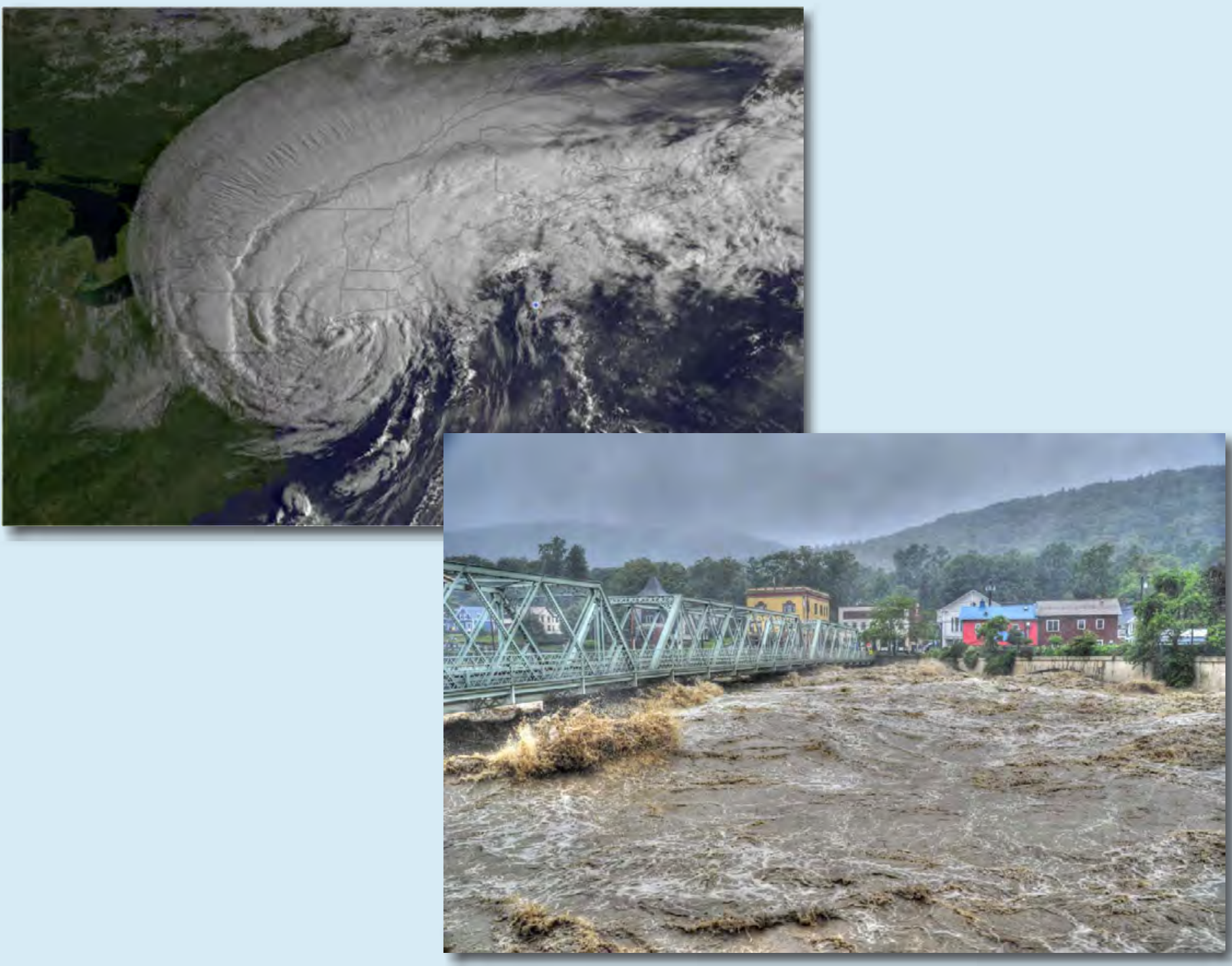

Scientific Investigations Report 2016-5027

U.S. Department of the Interior

U.S. Geological Survey 
Front cover. Upper left: Geostationary Operational Environmental Satellite (GOES) East image of Hurricane Irene making landfall near New York City on August 28, 2011. Image is courtesy of the National Oceanic and Atmospheric Administration, 2011. Lower right: Deerfield River at the Bridge Street bridge (left) and the Bridge of Flowers (right) at Shelburne Falls, Massachusetts, taken on August 28, 2011, during flood flows from tropical storm Irene. Photograph by John E. Robison, Amherst, Massachusetts.

Back cover. Maxam Road bridge on the West Branch North River in Colrain, Massachusetts, with the bridge structure at the right edge of the water (looking downstream) washed out on August 28, 2011, by tropical storm Irene. Photograph by Andrew Waite, USGS, taken on September 22, 2011. 


\section{Tropical Storm Irene Flood of August 2011 in Northwestern Massachusetts}

By Gardner C. Bent, Scott A. Olson, and Andrew J. Massey

Prepared in cooperation with the Federal Emergency Management Agency

Scientific Investigations Report 2016-5027 


\title{
U.S. Department of the Interior SALLY JEWELL, Secretary
}

\section{U.S. Geological Survey Suzette M. Kimball, Director}

\author{
U.S. Geological Survey, Reston, Virginia: 2016
}

For more information on the USGS - the Federal source for science about the Earth, its natural and living resources, natural hazards, and the environment-visit http://www.usgs.gov/ or call 1-888-ASK-USGS.

For an overview of USGS information products, including maps, imagery, and publications, visit http://www.usgs.gov/pubprod/.

Any use of trade, firm, or product names is for descriptive purposes only and does not imply endorsement by the U.S. Government.

Although this information product, for the most part, is in the public domain, it also may contain copyrighted materials as noted in the text. Permission to reproduce copyrighted items must be secured from the copyright owner.

Suggested citation:

Bent, G.C., Olson, S.A., and Massey, A.J., 2016, Tropical storm Irene flood of August 2011 in northwestern Massachusetts: U.S. Geological Survey Scientific Investigations Report 2016-5027, 28 p., http://dx.doi.org/10.3133/ sir20165027.

ISSN 2328-0328 (online) 


\section{Contents}

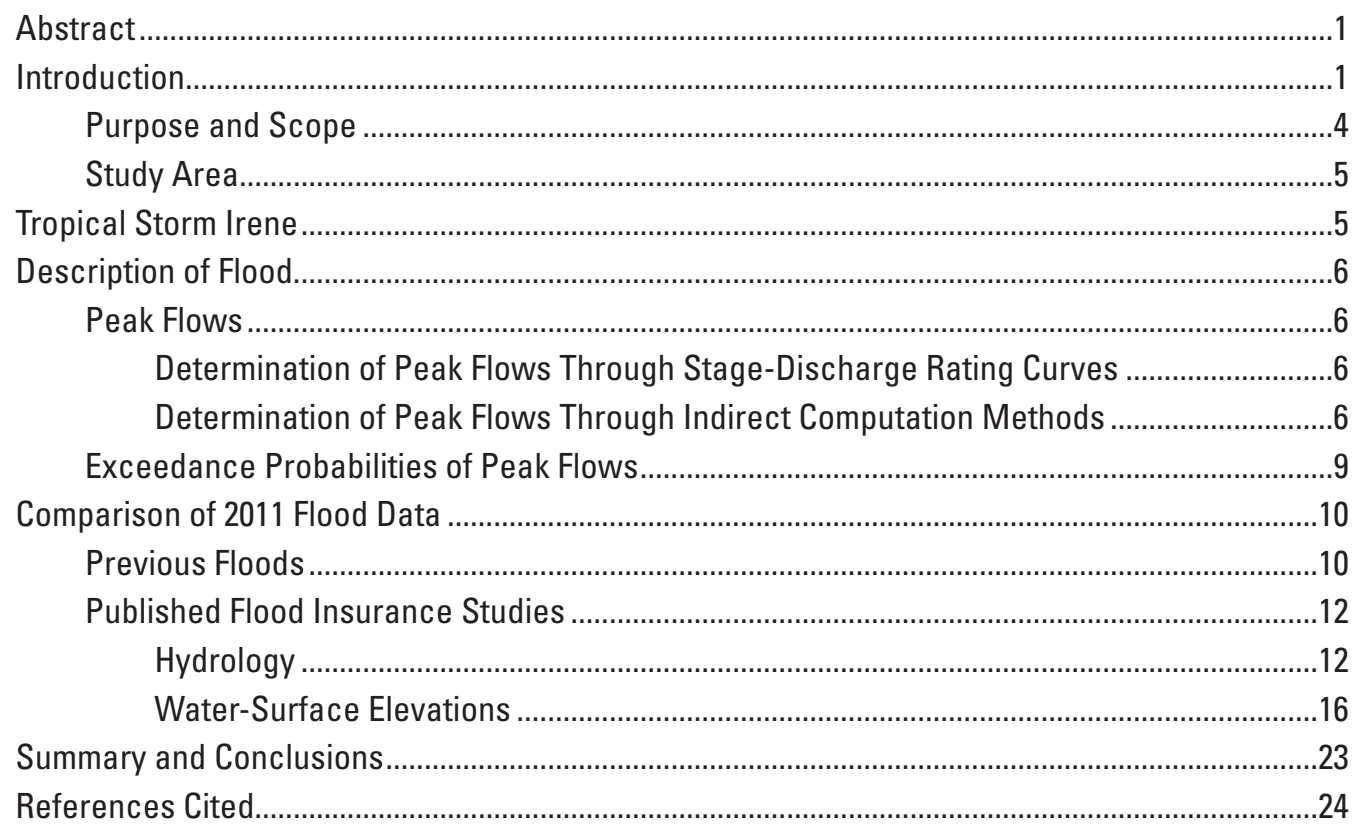

\section{Figures}

1. Map showing distribution of rainfall and path of tropical storm Irene across western Massachusetts on August 28-29, 2011

2. Map showing location of the study area and the estimated annual exceedance probability of the August 28, 2011, tropical storm Irene peak flows at U.S. Geological Survey streamgages in the Deerfield and Hoosic River Basins in northwestern Massachusetts.

3. Hydrographs showing a rapid rise in gage height because of runoff from tropical storm Irene, August 28, 2011, for U.S. Geological Survey streamgages $A$, Hoosic River near Williamstown, Massachusetts, and $B$, Deerfield River near West Deerfield, Mass.

4. Graph showing stage-discharge rating curve number 35 for U.S. Geological Survey Deerfield River at Charlemont, Massachusetts, streamgage.

5. Graphs showing annual peak flows through water year 2013 for streamgages $A$, Deerfield River at Charlemont, Massachusetts; $B$, Hoosic River at Adams, Mass.; and $C$, North Branch Hoosic River at North Adams, Mass.

\section{Tables}

1. Peak flows and gage heights for the August 28,2011 , flood compared with historical peaks for U.S. Geological Survey streamgages in the Deerfield and Hoosic River Basins, northwestern Massachusetts

2. Peak gage heights, flows, flow calculation method, and corresponding annual exceedance probabilities with confidence limits for the August 28, 2011, flood at streamgages in northwestern Massachusetts. 
3. Comparison of peak flows for selected annual exceedance probabilities computed with those published in the effective Federal Emergency Management Agency flood insurance studies for U.S. Geological Survey streamgages in the Deerfield and Hoosic River Basins, northwestern Massachusetts

4. Comparison of the simulated water-surface elevations for the Deerfield River for the 1-percent annual exceedance probability discharge determined by Lombard and Bent (2015b) with those published in the effective Federal Emergency Management Agency flood insurance studies

5. Comparison of the water-surface elevations for the Green River for the 1-percent annual exceedance probability discharge determined by Flynn and others (2016) with those published in the effective Federal Emergency Management Agency flood insurance study.

6. Comparison of the water-surface elevations for the North River for the 1-percent annual exceedance probability discharge determined by Bent and others (2015) with those published in the effective Federal Emergency Management Agency flood insurance study.

7. Comparison of the water-surface elevations for the Hoosic River for the 1-percent annual exceedance probability discharge determined by Lombard and Bent (2015a) with those published in the effective Federal Emergency Management Agency flood insurance studies

\section{Conversion Factors}

U.S. customary units to International System of Units

\begin{tabular}{lll}
\hline \multicolumn{1}{c}{ Multiply } & By & \multicolumn{1}{c}{ To obtain } \\
\hline inch (in.) & Length & \\
foot (ft) & 2.54 & centimeter $(\mathrm{cm})$ \\
mile (mi) & 0.3048 & meter $(\mathrm{m})$ \\
& 1.609 & kilometer $(\mathrm{km})$ \\
\hline square mile $\left(\mathrm{mi}^{2}\right)$ & Area & \\
\hline & 2.590 & square kilometer $\left(\mathrm{km}^{2}\right)$ \\
\hline cubic foot per second $\left(\mathrm{ft}^{3} / \mathrm{s}\right)$ & Flow rate & \\
mile per hour (mi/hr) & 0.02832 & cubic meter per second $\left(\mathrm{m}^{3} / \mathrm{s}\right)$ \\
\hline
\end{tabular}

Temperature in degrees Celsius $\left({ }^{\circ} \mathrm{C}\right)$ may be converted to degrees Fahrenheit $\left({ }^{\circ} \mathrm{F}\right)$ as follows:

$$
{ }^{\circ} \mathrm{F}=\left(1.8 \times{ }^{\circ} \mathrm{C}\right)+32 \text {. }
$$




\section{Datum}

Vertical coordinate information is referenced to the North American Vertical Datum of 1988 (NAVD 88).

Horizontal coordinate information is referenced to the North American Datum of 1983 (NAD 83).

Elevation, as used in this report, refers to distance above the vertical datum.

\section{Abbreviations}

$\begin{array}{ll}\text { AEP } & \text { annual exceedance probability } \\ \text { EMA } & \text { expected moments algorithm } \\ \text { FEMA } & \text { Federal Emergency Management Agency } \\ \text { FHWA } & \text { Federal Highway Administration } \\ \text { FIS } & \text { flood insurance study } \\ \text { HEC-RAS } & \text { Hydrologic Engineering Center-River Analysis System } \\ \text { HWM } & \text { high-water mark } \\ \text { MassDOT } & \text { Massachusetts Department of Transportation } \\ \text { NOAA } & \text { National Oceanic and Atmospheric Administration } \\ \text { USACE } & \text { U.S. Army Corps of Engineers } \\ \text { USGS } & \text { U.S. Geological Survey }\end{array}$





\title{
Tropical Storm Irene Flood of August 2011 in Northwestern Massachusetts
}

\author{
By Gardner C. Bent, Scott A. Olson, and Andrew J. Massey
}

\section{Abstract}

A Presidential disaster was declared in northwestern Massachusetts, following flooding from tropical storm Irene on August 28, 2011. During the storm, 3 to 10 inches of rain fell on soils that were susceptible to flash flooding because of wet antecedent conditions. The gage height at one U.S. Geological Survey streamgage rose nearly 20 feet in less than 4 hours because of the combination of saturated soils and intense rainfall. On August 28, 2011, in the Deerfield and Hoosic River Basins in northwestern Massachusetts, new peaks of record were set at six of eight U.S. Geological Survey long-term streamgages with 46 to 100 years of record. Additionally, high-water marks were surveyed and indirect measurements of peak discharge were calculated at two discontinued streamgages in the Deerfield and Hoosic River Basins with 24 and 61 years of record, respectively. This data resulted in new historic peaks of record at the two discontinued streamgages from tropical storm Irene.

Peak flows that resulted from tropical storm Irene (August 28, 2011) were determined at the U.S. Geological Survey streamgages by using stage-discharge rating curves and indirect computation methods. For six streamgages, indirect computation methods were used to compute the peak flows. Peak flows from tropical storm Irene had annual exceedance probabilities (AEPs) that ranged from 5.4 percent to less than 0.2 percent at 10 streamgages in northwestern Massachusetts.

Discharges calculated for select AEPs as a part of this study were compared with discharges published for the same AEPs in the effective Federal Emergency Management Agency flood insurance studies (FISs) for communities in the study area. Discharges estimated for the 10-, 2-, 1-, and 0.2-percent AEPs at two streamgages on the main stem of the Deerfield River ranged from about 3 percent lower to 14 percent higher than discharges in the FISs. AEP discharges calculated for two streamgages on tributaries to the Deerfield River were 27 to 89 percent higher than the FISs. For the four streamgages in the Hoosic River Basin, the 10-, 2-, 1-, and 0.2-percent AEP discharges calculated ranged from about 33 percent lower to 5 percent higher than the FISs.

The simulated 1-percent AEP discharge water-surface elevations (nonregulatory) from recent (2015-16) hydraulic models for river reaches in the study area, which include the Deerfield, Green, and North Rivers in the Deerfield River Basin and the Hoosic River in the Hoosic River Basin, were compared with water-surface profiles in the FISs. The watersurface elevation comparisons were generally done downstream and upstream from bridges, dams, and major tributaries. The simulated 1-percent AEP discharge water-surface elevations of the recent hydraulic studies averaged 2.2, 2.3, 0.3 , and $0.7 \mathrm{ft}$ higher than water-surface elevations in the FISs for the Deerfield, Green, North, and Hoosic Rivers, respectively. The differences in water-surface elevations between the recent (2015-16) hydraulic studies and the FISs likely are because of (1) improved land elevation data from light detection and ranging (lidar) data collected in 2012, (2) detailed surveying of hydraulic structures and cross sections throughout the river reaches in 2012-13 (reflecting structure and cross section changes during the last 30-35 years), (3) updated hydrology analyses (30-35 water years of additional peak flow data at streamgages), and (4) high-water marks from the 2011 tropical storm Irene flood being used for model calibration.

\section{Introduction}

Rainfall of 3 to 10 inches from tropical storm Irene resulted in record flooding on August 28-29, 2011, in western Massachusetts (fig. 1). On the basis of preliminary damage assessments, President Obama declared a major disaster in the Commonwealth of Massachusetts on September 3, 2011, with individual and public assistance available for Berkshire and Franklin Counties (fig. 1; Federal Emergency Management Agency, 2015). On October 20, 2011, the Presidential disaster (FEMA-4028-DR) also designated Hampden and Hampshire Counties in western Massachusetts (fig. 1; plus five other counties in eastern Massachusetts) as eligible for public assistance (Federal Emergency Management Agency, 2015). As of July 2015, Federal financial assistance to Massachusetts for recovery from tropical storm Irene totaled more than $\$ 5.5$ million approved for individual assistance and more than $\$ 29.7$ million obligated for public assistance (Federal Emergency Management Agency, 2015). Kinney (2011a) reported that tropical storm Irene resulted in more than 


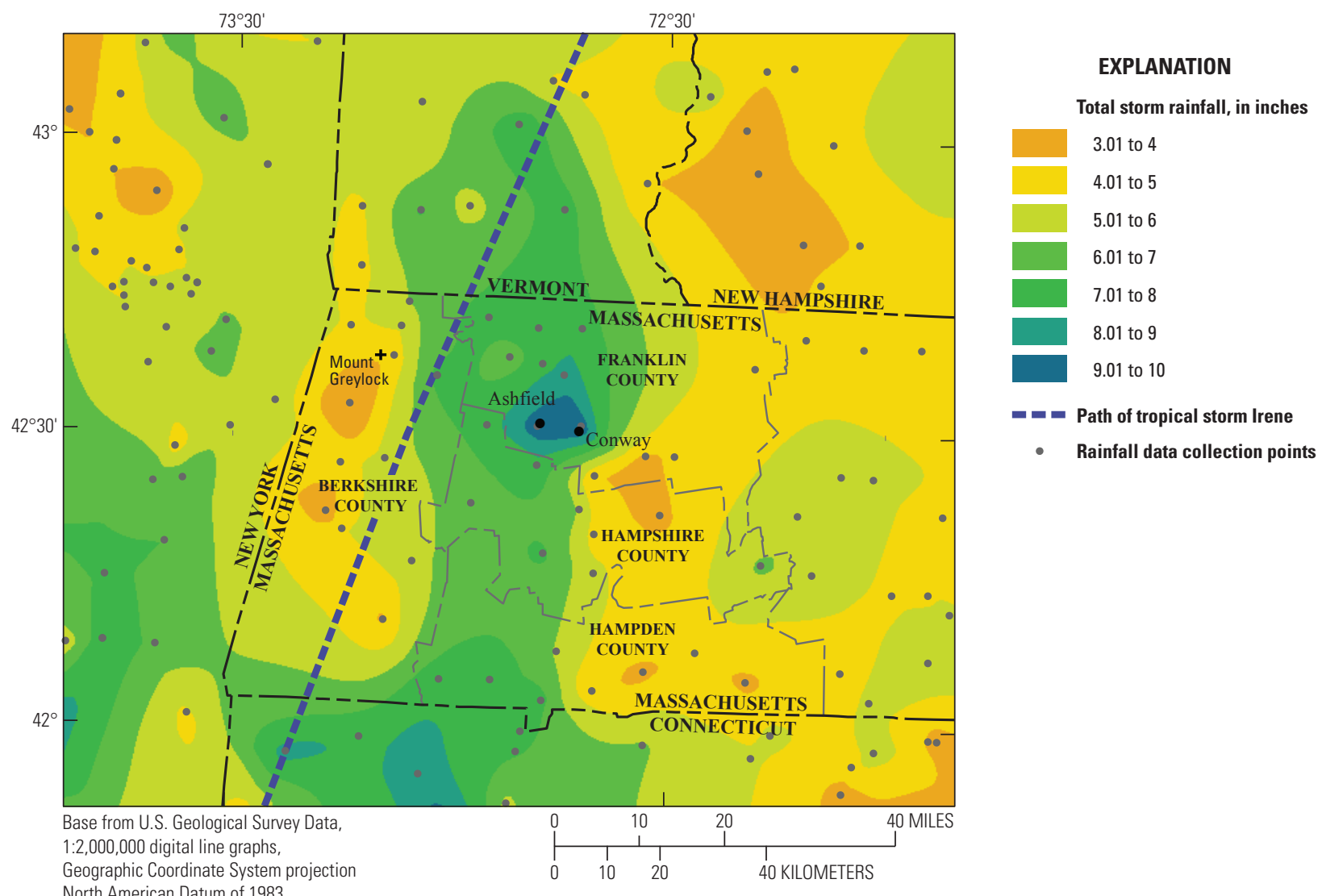

Figure 1. Distribution of rainfall and path of tropical storm Irene across western Massachusetts on August 28-29, 2011. Information on the rainfall data collection points and the path of tropical storm Irene is from the National Oceanic and Atmospheric Administration (2011) and National Weather Service (2011).

$\$ 90$ million in insurance claims in western Massachusetts, including more than $\$ 750,000$ in Franklin County.

The Massachusetts Department of Transportation (MassDOT) reported about $\$ 35$ million in damage to bridges and roads as a result of tropical storm Irene in north Berkshire County and Franklin County in northwestern Massachusetts (Massachusetts Department of Transportation, 2011b). A 5.8-mile section of State Route 2, the primary east-west highway in northwestern Massachusetts, was one of the most visible damages from Irene, which resulted in State Route 2 being closed for more than 3 months following Irene (Massachusetts Department of Transportation, 2012a). Several sections of State Route 2 were eroded and collapsed into the Cold River, and four landslides crossed the highway (Mabee and others, 2013). Immediately following tropical storm Irene, MassDOT received \$4.65 million from the Federal Highway Administration (FHWA) for emergency repairs to roads and bridges primarily in Berkshire and Franklin Counties (Massachusetts Department of Transportation, 2011a). In January 2012, MassDOT received a second grant of nearly \$41 million from FHWA for damages to bridges and roads because of Irene; a large portion of the grant was for repairs to State Route 2 (Flynn, 2012; Massachusetts Department of Transportation, 2012b).

Other damages from tropical storm Irene flood flows in the Deerfield River Basin (fig. 2) were along the main stem of the Deerfield River (fig. 2) and along many of the tributaries to the Deerfield River. Numerous homes, businesses, schools, municipal infrastructure, and agricultural fields along the Deerfield River were flooded, specifically in Buckland, Charlemont, Deerfield, Greenfield, and Shelburne (fig. 2; Massachusetts Emergency Management Agency, 2011). During the height of tropical storm Irene and in some cases for several days following the storm, several bridges over the Deerfield River and roads in western Massachusetts were closed, such as the bridges over the Deerfield River on Route 8A, Route 2A, Stillwater Road, and U.S. Interstate I-91 (Abel, 2011; Johnson, 2011; Kinney, 2011b; Republican Newsroom, The, 2011; Schworm and Lutz, 2011). A building (a quilt store in Buckland) along the Deerfield River was washed away from its foundation and was deposited downstream less than 100 feet (ft; Barry, 2011). In the town 

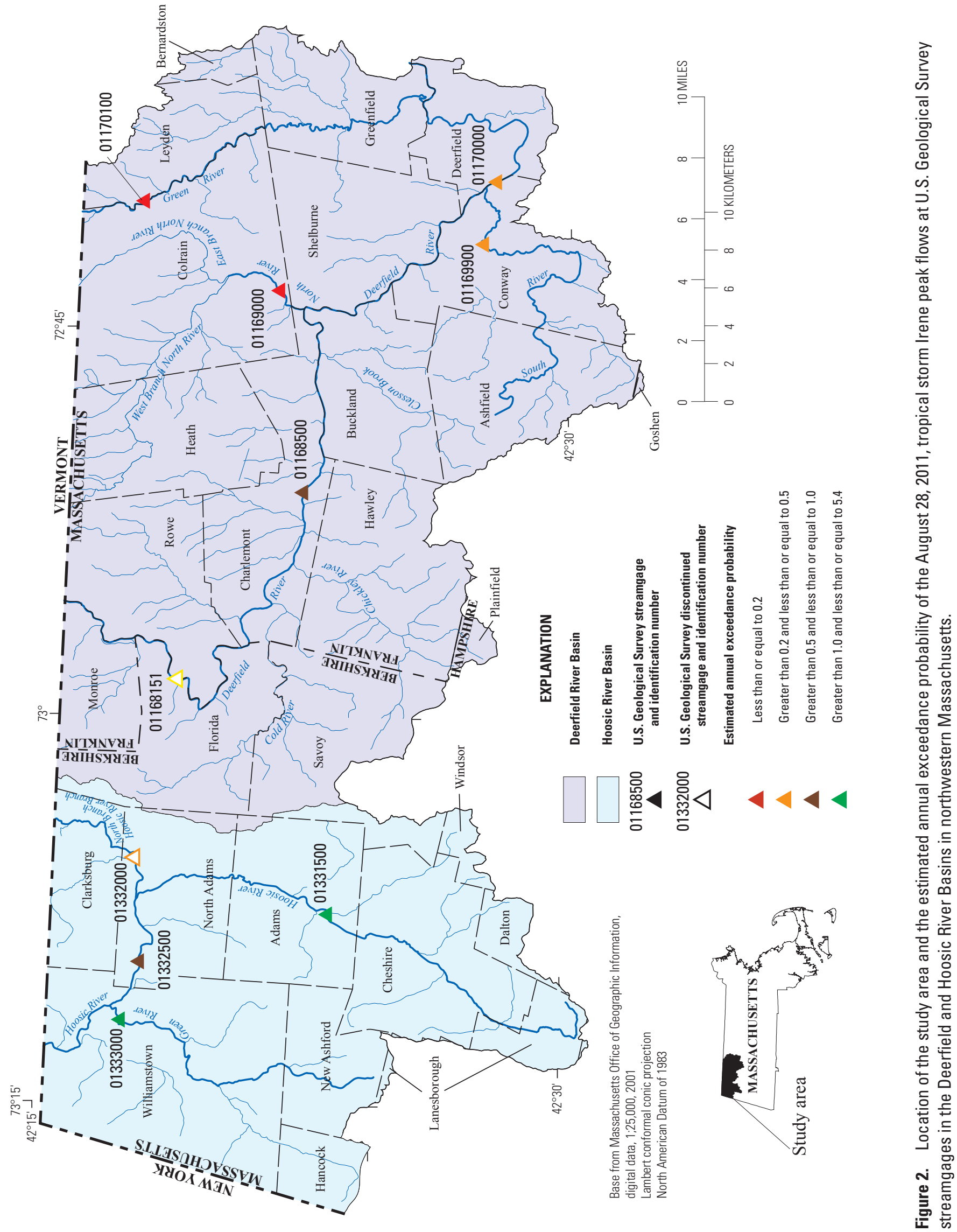
of Deerfield, damages were reported in the village of Old Deerfield, at the Deerfield Academy, at the Bement School, to municipal infrastructure, and to farm fields because of flooding from the Deerfield River (Gilmore and others, 2011).

The town of Greenfield estimated damages of $\$ 11$ million, mainly to the infrastructure (Stabile, 2011). The Greenfield wastewater treatment plant on the Green River, near the confluence of the Green River with the Deerfield River, was inundated by flood waters, resulting in a shutdown and untreated wastewater discharging to the Deerfield River and Connecticut River (at the mouth of Deerfield River, not shown on fig. 2; Graham, 2011). Other damaged infrastructure along the Green River in Greenfield included the washout of Eunice Williams Road at a historic covered bridge, which was caused by the upstream failure of a segment of the dam for the Greenfield Water Supply Pumping Station. The Green River Swimming and Recreation Area in Greenfield had extensive damage because of flooding. Several private homes and businesses along the Green River also were damaged. For example, a private home was destroyed just upstream from West Leyden Road on the Colrain and Leyden (fig. 2) town border, a business on the downstream side of Colrain Road in Greenfield was flooded, and the first floor of the Museum of Our Industrial Heritage, on the downstream side of Mill Street/ River Street in Greenfield, was flooded.

The well field of the village of Shelburne Falls within the town of Shelburne along the North River (fig. 2) in the midsection of the study reach in Colrain was inundated during tropical storm Irene (Murphy, 2013). The Barnhardt Manufacturing Company building along the North River in Colrain was flooded, and the Barnhardt dam (not shown), just downstream from the confluence of the East Branch North River and West Branch North River (fig. 2), was breached. On the East Branch North River in the town of Colrain, a streambank slope was eroded near the salt barn, and the highway garage and basement were flooded (Murphy, 2013). On the West Branch North River in Colrain, the Maxam Road bridge was partially washed out.

Damages from tropical storm Irene flood flows in the Hoosic River Basin primarily were on the North Branch Hoosic River and downstream from the U.S. Geological Survey (USGS) Hoosic River near Williamstown, Massachusetts, streamgage (01332500; fig. 2). The Spruces Mobile Home Park, 1 mile downstream from the streamgage, was severely affected by the flooding; two-thirds of the 226 mobile homes were damaged or destroyed (Andy McKeever, iBerkshire, written commun., 2011; Tammy Daniels, iBerkshire, written commun., 2013). The town of Williamstown (fig. 2) received a \$6.13 million Federal Emergency Management Agency (FEMA) hazard mitigation grant to relocate the remaining residents of the Spruces Mobile Home Park, and a notice of discontinuance was signed by the town in February 2014 stating that the mobile home park will close February 29, 2016 (Edward Damon, Berkshire Eagle, written commun., 2013).

Other roads, bridges, private homes, and businesses were damaged from flood waters on smaller tributaries in the Deerfield and Hoosic River Basins in northwestern Massachusetts. Several of the damages were along Clesson Brook, Cold River, and South River (fig. 2); several other damages were reported that are not presented in this study.

In response to the Presidential disaster declaration for Massachusetts resulting from tropical storm Irene (DR-4028), a FEMA mission assignment was authorized for the USGS to identify and flag high-water marks (HWMs) in western Massachusetts, specifically along river reaches in the Deerfield and Hoosic River Basins and to survey their elevations. In April 2012, an interagency agreement between FEMA Region I (New England) and USGS authorized the following specific tasks: surveying of HWM elevations to the North American Vertical Datum of 1988 (NAVD 88) for selected river reaches, collecting and processing light detection and ranging (lidar) elevation data, comparing data in the effective FEMA flood insurance studies (FISs; the effective FEMA FISs are hereafter referred to as the FISs) from the late 1970s and early 1980s to data updated through 2011, producing hydraulic models for selected river reaches, and generating flood-inundation and recovery maps for selected river reaches in western Massachusetts as a result of tropical storm Irene. The HWM elevation data that were collected following the tropical storm Irene flooding on selected rivers in the study area were published by Bent and others (2013). The lidar data collected for this study are available as digital elevation model (DEM) data through the Massachusetts Office of Geographic Information System (MassGIS) (2015), and the data accuracy and other information are available from the National Oceanic and Atmospheric Administration (2013). The flood-inundation maps for the Deerfield River, Green River, North River, and Hoosic River can be viewed on the USGS flood-inundation mapping Web site at http://wimcloud.usgs.gov/apps/FIM/ FloodInundationMapper.html, and the flood recovery maps are available as shapefiles with the reports (Lombard and Bent, 2015a; Flynn and others, 2016; Bent and others, 2015; and Lombard and Bent, 2015b, respectively).

\section{Purpose and Scope}

The purpose of this report is to summarize the tropical storm Irene flooding on August 28, 2011, in northwestern Massachusetts. The report evaluates the estimated 10-, 2-, $1-$, and 0.2-percent annual exceedance probability (AEP) discharges at USGS streamgages and the simulated 1-percent AEP discharge water-surface elevation of hydraulic models for selected river reaches in the Deerfield and Hoosic River Basins and compares the results to the FISs' AEP discharges and water-surface elevations. This report also presents a summary of the gage heights and peak flows at USGS streamgages during tropical storm Irene and describes methods used to estimate the flood flows and the AEPs. The August 28, 2011, tropical storm Irene flood flows are also compared with selected previous historic floods in northwestern Massachusetts. 


\section{Study Area}

The study area is the Deerfield and Hoosic River Basins in northwestern Massachusetts (fig. 2). Elevations in the study area range from Mount Greylock at 3,487 ft to about $120 \mathrm{ft}$ above sea level at the mouth of the Deerfield River. Northwestern Massachusetts is within the Hudson-GreenNotre Dame and Taconic Highlands and the Connecticut and Vermont Valley physiographic provinces (Denny, 1982, plate 1, fig. 3) and is fairly rural with most of the population living in the river valleys of the major river basins. The land use is primarily forested with some agricultural areas generally in the river valleys. The Deerfield River has a drainage area of 665 square miles $\left(\mathrm{mi}^{2}\right)$ in Vermont and Massachusetts $\left(347 \mathrm{mi}^{2}\right.$ in Massachusetts), has multiple hydroelectric facilities, and
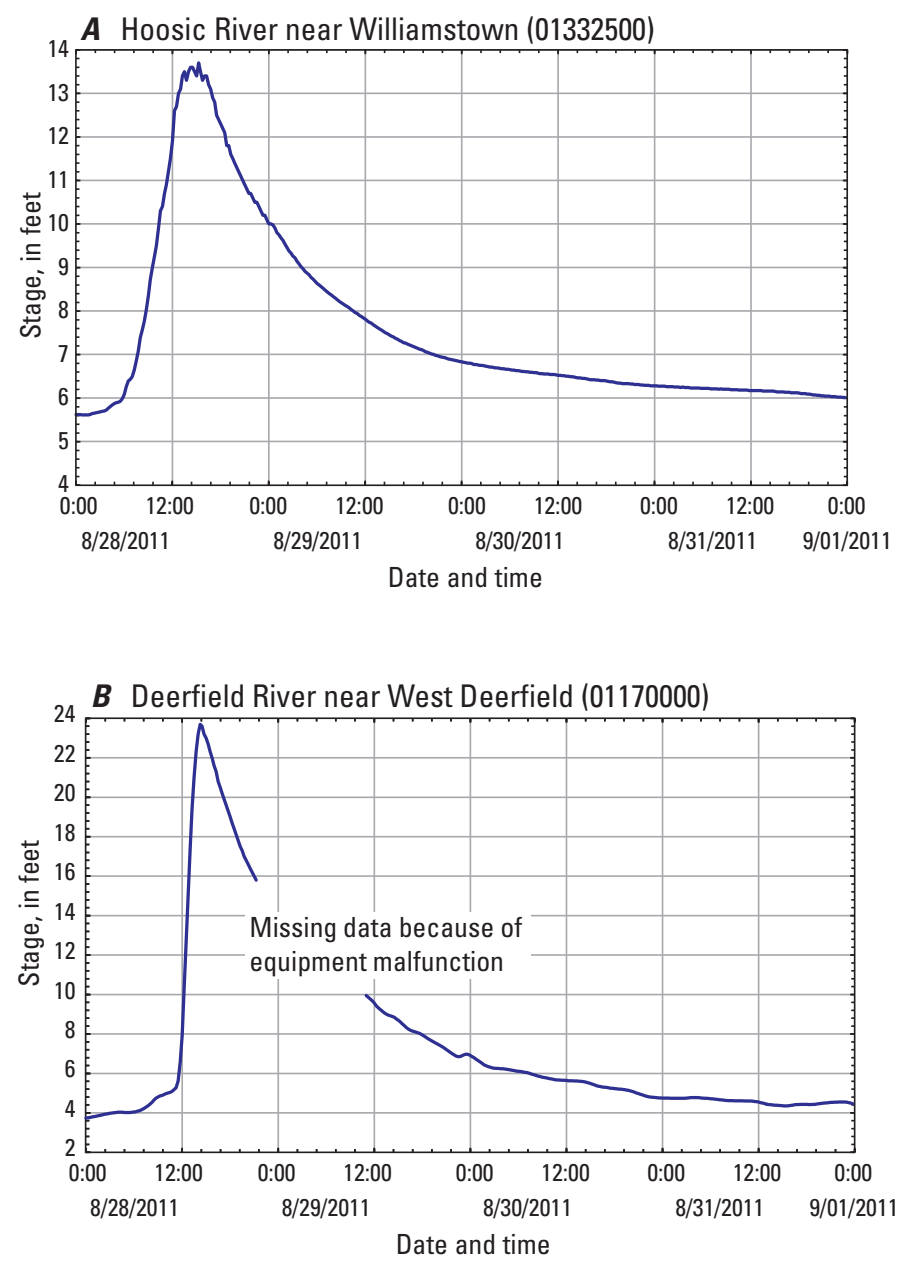

Figure 3. A rapid rise in gage height (stage) because of runoff from tropical storm Irene, August 28, 2011, for U.S. Geological Survey streamgages $A$, Hoosic River near Williamstown, Massachusetts (01332500), and $B$, Deerfield River near West Deerfield, Mass. (01170000). is a popular fishing destination having native and stocked trout (Deerfield River Watershed Association, 2005). The Deerfield River flows generally eastward and discharges into the Connecticut River. The Hoosic River Basin in Massachusetts is about $240 \mathrm{mi}^{2}$ and sustains native wild trout (Commonwealth of Massachusetts, 2016). The Hoosic River (fig. 2) generally flows northward into Vermont and New York before discharging into the Hudson River (not shown) in New York.

Climate in the Deerfield and Hoosic River Basins is fairly uniform. In Greenfield (National Oceanic and Atmospheric Administration[NOAA] station USC00193229), the annual mean precipitation is 49.50 inches and the annual mean temperature is 47.0 degrees Fahrenheit $\left({ }^{\circ} \mathrm{F}\right)$, which is based on data from 1981 to 2010 (National Oceanic and Atmospheric Administration, National Centers for Environmental Information, 2016a). In North Adams (NOAA station USW00054768), the annual mean precipitation is 46.61 inches and the annual mean temperature is $46.8^{\circ} \mathrm{F}$, based on data from 1981 to 2010 (National Oceanic and Atmospheric Administration, National Centers for Environmental Information, 2016a). In Ashfield (figs. 1, 2; NOAA station USC00190213), the annual mean precipitation is 51.73 inches and the annual mean temperature is $44.0^{\circ} \mathrm{F}$, which is based on data from 1981 to 2010 (National Oceanic and Atmospheric Administration, National Centers for Environmental Information, 2016a).

\section{Tropical Storm Irene}

Irene began as a tropical storm on August 21, 2011, about 140 miles east of Martinique in the Caribbean (not shown), and passed over the island of St. Croix (not shown) that same day (Avila and Cangialosi, 2011, p. 1-3, fig. 1). As tropical storm Irene moved west-northwest and passed over eastern Puerto Rico (not shown) on August 22, 2011, the storm became a hurricane. Hurricane Irene then moved northwest, and on August 24, 2011, Irene became a category 3 hurricane. As Hurricane Irene moved about 200-300 miles offshore of Florida (not shown) on August 25, Irene turned northward up the coastline of the United States. On August 27, 2011, Hurricane Irene made landfall near Cape Lookout, North Carolina (not shown), as a category 1 hurricane and then moved back out to sea just southeast of Norfolk, Virginia (not shown), continuing northward as the hurricane skirted the Delmarva peninsula (not shown) (Fanelli and Fanelli, 2011, p. 2, figs. 1, 2A, $C$, and $D$ ). On the morning of August 28, 2011, Hurricane Irene made landfall a second time near Little Egg Inlet, New Jersey (not shown). Hurricane Irene quickly weakened and was downgraded to a tropical storm before moving briefly back out to sea near Sandy Hook, N.J., (not shown) and then making landfall a final time late in the morning of August 28 at Coney Island in Brooklyn, New York (not shown). Tropical storm Irene continued moving northnortheastward across western Connecticut and Massachusetts 
(fig. 1) and along the New Hampshire-Vermont border and up into northwestern Maine (not shown; Fanelli and Fanelli, 2011, p. 1, figs. 1 and 2C).

Irene caused damages from rainfall, wind damage, and storm surge along the east coast of the United States and in the Caribbean. Along the east coast of the United States from North Carolina to Maine, rainfall amounts ranged from less than 3 inches to almost 16 inches (Avila and Cangialosi, 2011). This area includes the noncoastal States of Pennsylvania (not shown) and Vermont, which had areas with at least 5 inches of rainfall. Maximum sustained wind speeds from South Carolina to Massachusetts ranged from about 40 to 80 miles per hour, with the highest along the North Carolina coast (Fanelli and Fanelli, 2011, tables $2 A-C$ ). Storm surge along the coast from Florida to Maine generally ranged from about 1 to $7 \mathrm{ft}$ at tidal gages and temporary storm tide sensors (Fanelli and Fanelli, 2011, tables 3A-C; McCallum and others, 2012).

Rainfall totals in northwestern Massachusetts ranged from about 3 to 10 inches (fig. 1). The highest observed rainfall totals from Irene in western Massachusetts were 9.92 inches in Conway and 9.75 inches in Ashfield (National Weather Service, 2011). The NOAA, National Centers for Environmental Information (2016b) ranked August 2011 as the second wettest August in 117 years of precipitation records for Massachusetts. Rainfall in western Massachusetts during August 2011 was 11.21 inches, more than three times higher than the average August rainfall (3.41 inches; Massachusetts Department of Conservation and Recreation, 2011). During August 2011, before the arrival of tropical storm Irene, western Massachusetts had saturated soils from abundant rainfall, resulting in conditions susceptible to flash flooding (Lubchenco and Furgione, 2012).

\section{Description of Flood}

In the Deerfield and Hoosic River Basins, new record peak flows were recorded at 8 of 10 long-term ( 24 or more years of record) USGS streamgages in northwestern Massachusetts on August 28, 2011, from tropical storm Irene (fig. 2, table 1). Of the 10 streamgages, eight had new record peak gage heights. The Hoosic River near Williamstown, Mass., streamgage (01332500) had a new peak flow; however, the gage height was not a new peak of record because the streamgage was relocated and the gage datum was changed in 1979. The Deerfield River near Rowe, Mass., and the North Branch Hoosic River at North Adams, Mass., streamgages (01168151 and 01332000, respectively; fig. 2; table 2) were discontinued at the time of tropical storm Irene; thus, the gage heights were estimated from HWMs, and the peak flow was estimated through indirect computation of discharge.

Most of the USGS streamgages reached peak gage heights within about 20 hours of the start of the rainfall (table 1), similarly to the Hoosic River near Williamstown,
Mass., streamgage (01332500; fig. $3 A$ ). Some streamgages reached a peak gage height in about 9-18 hours; for example, the gage height at the Deerfield River near West Deerfield, Mass., streamgage (0117000) increased from about $5 \mathrm{ft}$ to nearly $24 \mathrm{ft}$ in less than 4 hours (fig. $3 B$ ). This rapid response resulted from wet antecedent soil conditions (Lubchenco and Furgione, 2012) and intense rainfall.

\section{Peak Flows}

Peak flows for the streamgages in northwestern Massachusetts were determined by either using the stage-discharge rating curve method or the indirect discharge measurement method. The peak flows provided herein supersede those published in Bent and others (2013), Olson and Bent (2013), Olson (2014), Suro and others (2016), and USGS annual water data reports (U.S. Geological Survey, 2012a).

\section{Determination of Peak Flows Through Stage- Discharge Rating Curves}

Typically, stage-discharge rating curves (fig. 4, table 2) are used to compute the peak flows. The rating curves are developed on the basis of discharge measurements (including indirect discharge measurements) made during a wide range in stage. These stage-discharge ratings allow for continuous determination of discharge from recorded stage values.

\section{Determination of Peak Flows Through Indirect Computation Methods}

For streamgages, peak flows occasionally have to be computed by using indirect computation methods. Indirect computation methods are commonly done because the streamgage has been inactive, the flood is extreme, the estimated peak flow is more than five times than the highest discharge measurement made, the site is inaccessible under the peak flow conditions, streamflow measuring equipment cannot function properly in the extreme flow with debris or ice, or the flow cannot be safely measured (Benson and Dalrymple, 1967). The common methods of indirect computation of streamflow are slope area, contracted width opening (bridges), and flow over dams (weirs). The slope-area computation method is documented by Dalrymple and Benson (1968), and a program graphical user interface (GUI) is available for computation (Bradley, 2012). The contracted-width opening method is documented by Matthai (1967). The dam method is documented in Hulsing (1967) and in Horton (1907). All three methods were used to determine August 2011 peak flows in northwestern Massachusetts. First, HWMs were determined for a reach of river, upstream and downstream from a bridge or from a weir near the streamgage. River cross sections and the dimensions of the bridges or dams were surveyed and documented according to techniques outlined in Benson and 
Description of Flood

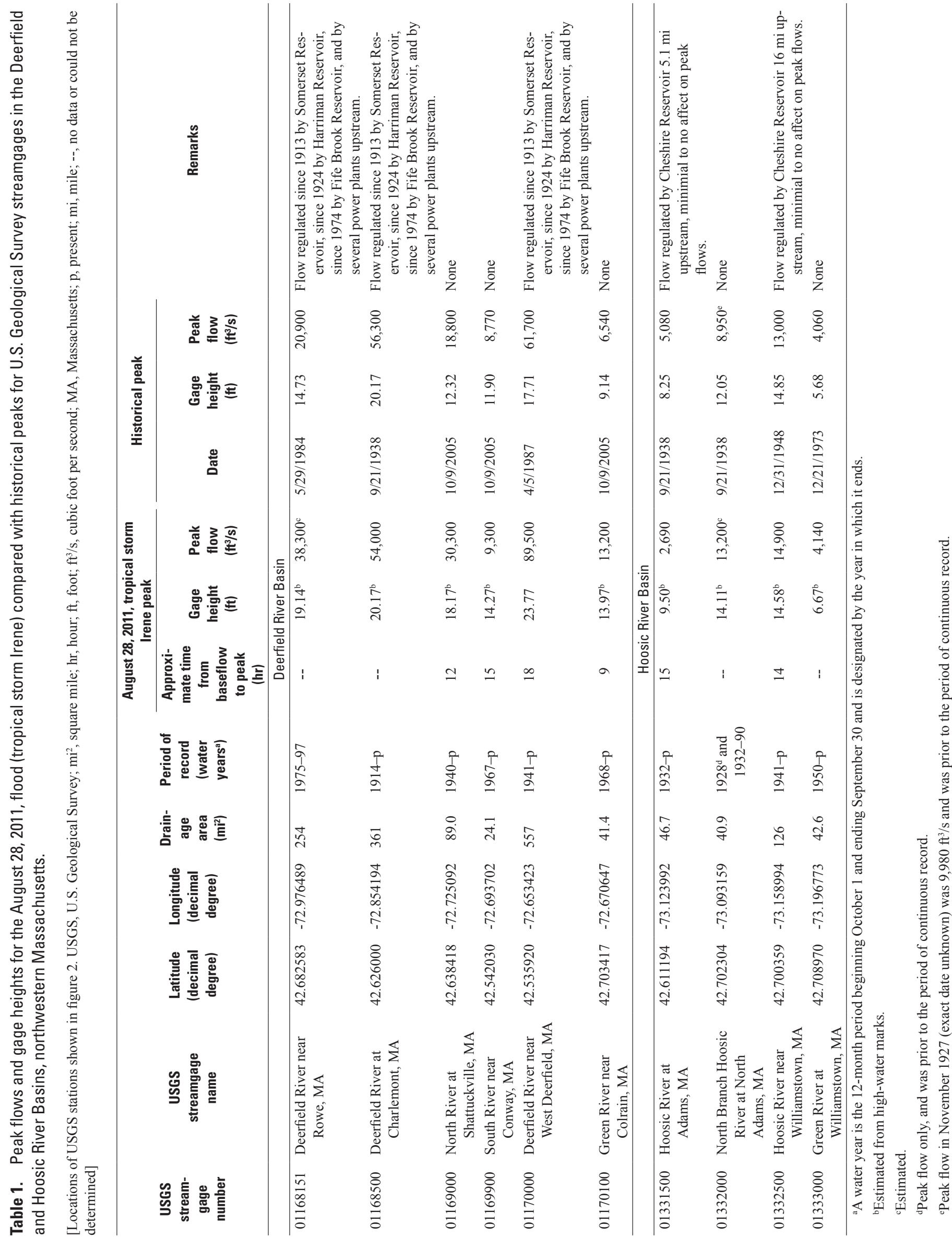




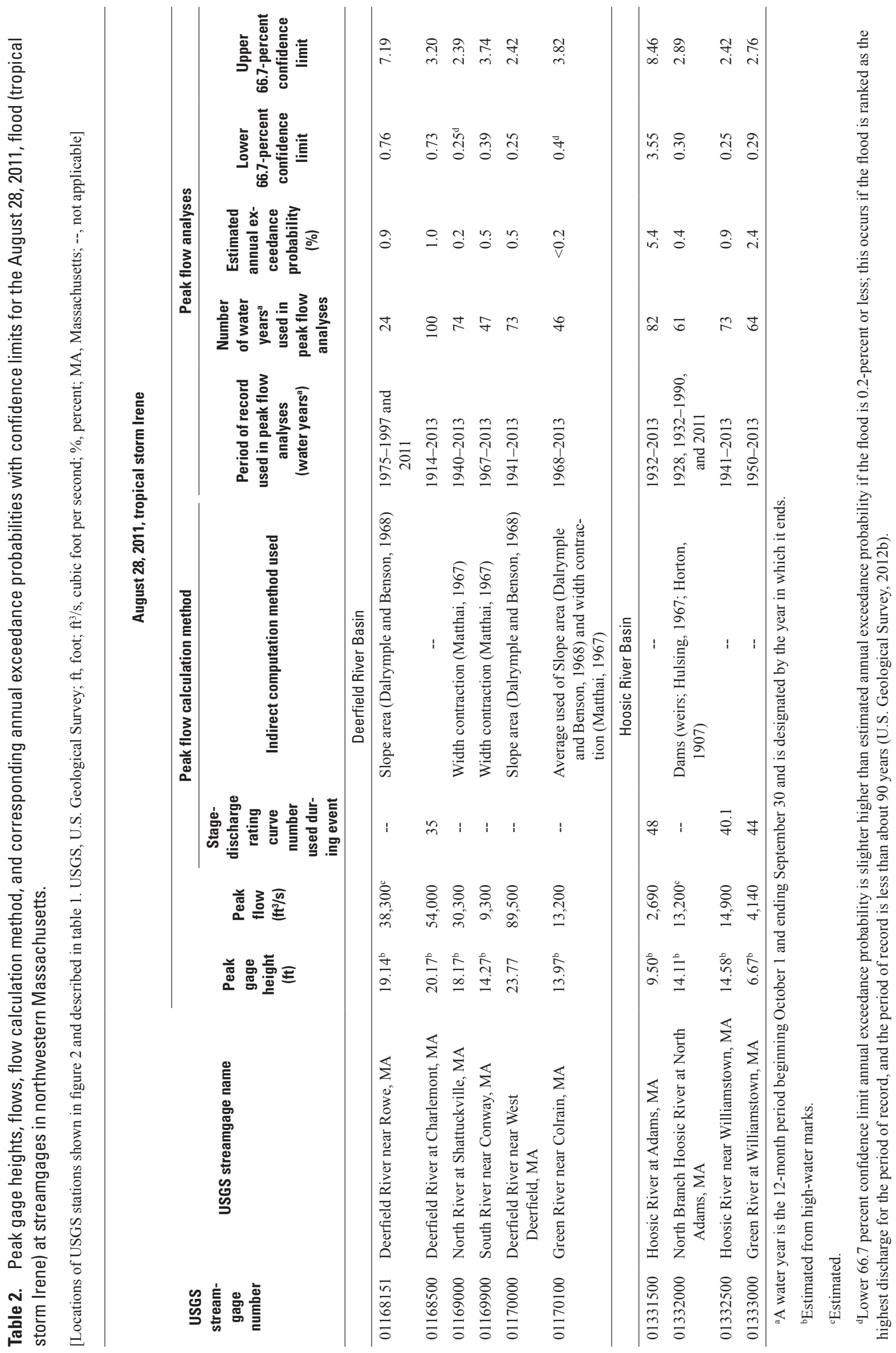




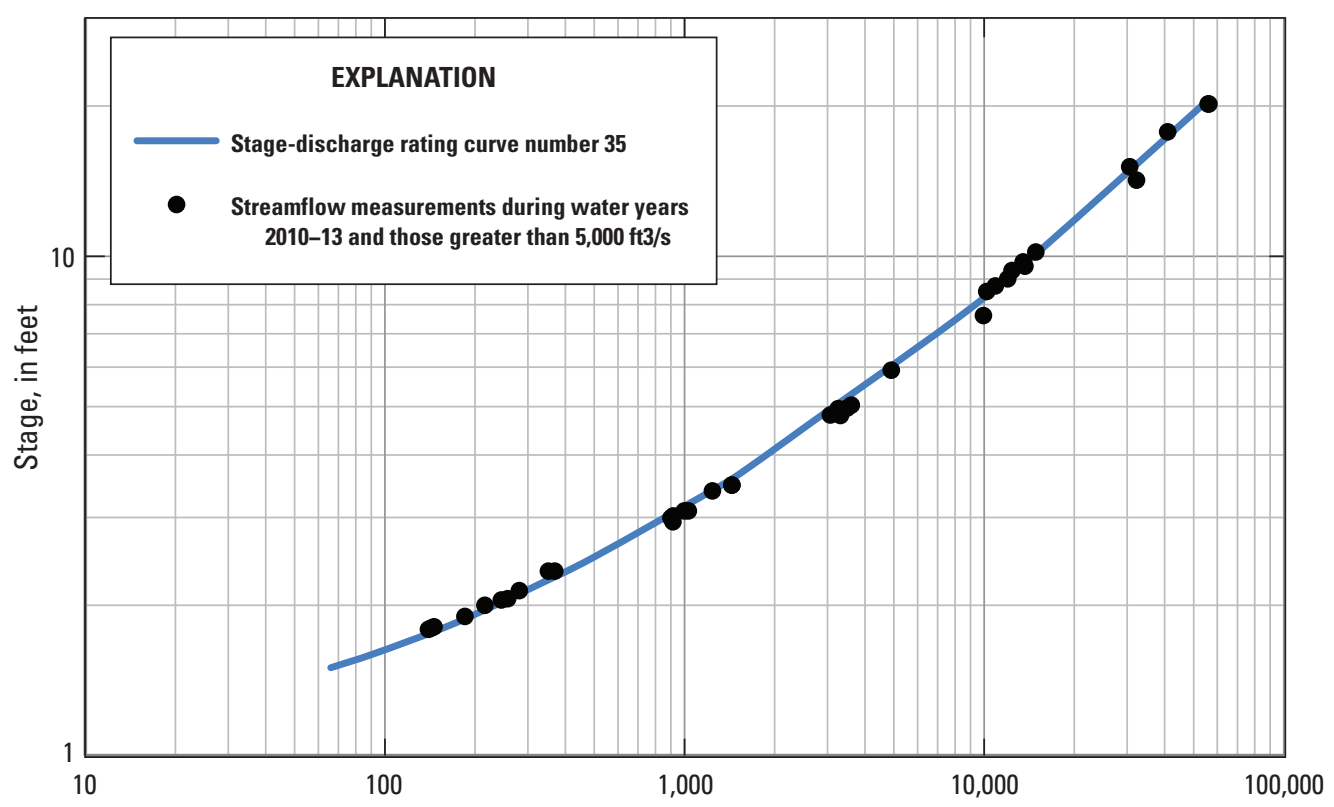

Streamflow, in cubic feet per second

Figure 4. Stage-discharge rating curve number 35 (active during tropical storm Irene on August $28,2011)$ for U.S. Geological Survey Deerfield River at Charlemont, Massachusetts, streamgage (01168500). A water year is the 12-month period beginning October 1 and ending September 30 and is designated by the year in which it ends.

Dalrymple (1967), Dalrymple and Benson (1968), Matthai (1967), and Hulsing (1967). Following tropical storm Irene, seven indirect measurements were done to estimate the peak flow at six streamgages (table 2). At the Green River near Colrain, Mass., streamgage (01170100), two indirect measurements were done; a slope-area computation and a contractedwidth opening method. The two methods produced estimates that were within about 6 percent of each other; thus, the average of the two methods was used as the discharge for the peak. At the two discontinued streamgages, the Deerfield River near Rowe, Mass. (01168151), and the North Branch Hoosic River at North Adams, Mass. (01332000), the HWMs were considered very poor; thus, the computation of the indirect measurements was considered an estimate. At the remaining four streamgages, the peak flow was computed from the stagedischarge rating curve that was in effect for each streamgage on August 28, 2011 (table 2).

\section{Exceedance Probabilities of Peak Flows}

Peak flows for selected AEPs were calculated for the 10 streamgages in the Deerfield and Hoosic River Basins by using annual peak flow data through water year ${ }^{1} 2013$ available through the USGS National Water Information System

${ }^{1} \mathrm{~A}$ water year is the 12-month period beginning October 1 and ending September 30 and is designated by the year in which it ends.
Web interface (NWISWeb; U.S. Geological Survey, 2014). The eight currently (2016) operated streamgages had from 46 to 100 years of annual peak flow data, and the two discontinued streamgages had from 24 to 61 years (table 2). Calculations were made by using the expected moments algorithm (EMA; Cohn and others, 1997, 2001; Griffis and others, 2004) in the USGS PeakFQ software (Veilleux and others, 2014). For the seven streamgages with no regulations of peak flows, the AEP estimate can be improved by combining the at-site EMA estimate with a regional regression equations estimate. The two AEP estimates (at-site EMA and regional regression equation) are weighted by the inverse of the variance of each of the discharge estimates (Cohn and others, 2012). The regional regression equations used in this process were those for Vermont (Olson, 2014). The three Deerfield River streamgages near Rowe, at Charlemont, and near West Deerfield, Mass. (01168151, 01168500, and 01170000, respectively), were not weighted with the Vermont regional regression equations (Olson, 2014) because the peak flows are likely affected by streamflow regulation (dams on the river). The AEPs estimated at the three Deerfield River streamgages are based only on the EMA analyses. The estimated AEPs and associated lower and upper 66.7-percent confidence limits for the August 28, 2011, flood are listed in table 2 for the 10 streamgages in the Deerfield and Hoosic River Basins.

Along the main stem of the Deerfield River (fig. 2), the tropical storm Irene (August 28, 2011) peak flows at the three 
streamgages had fairly similar AEPs that ranged from about 1 to 0.5 percent (table 2). For the three streamgages on the Green, North, and South Rivers (tributaries to the Deerfield River; fig. 2), the Irene peak flows had AEPs that ranged from about 0.5 to less than a 0.2 percent (table 2). The area where the Green, North, and South River Basins are located is generally where the higher rainfall amounts from Irene occurred (figs. 1, 2).

In the Hoosic River Basin, the Irene peak flows had AEPs that ranged from about 5.4 to 0.4 percent (table 2). The North Branch Hoosic River at North Adams, Mass., streamgage (01332000) had the lowest AEP and generally drains the area of the Hoosic River Basin that had the higher rainfall (figs. 1, 2). The peak flows at the Green River at Williamstown, Mass., and the Hoosic River at Adams, Mass., streamgages (01333000 and 01331500, respectively), which flow from the south to north, had slightly higher AEPs. The higher AEPs were likely related to lower rainfall in the river basins near Mount Greylock (figs. 1, 2).

\section{Comparison of 2011 Flood Data}

The tropical storm Irene, August 28, 2011, peak flows were compared with the peak flows of the selected floods that previously affected northwestern Massachusetts. Although several floods have affected western Massachusetts, the flood of November 1927 (Kinnison, 1930), the floods of March 1936 (Massachusetts Geodetic Survey, 1936; Grover, 1937a,b), the floods of September 1938 (Massachusetts Geodetic Survey, 1939; Paulsen, 1940), the New Year flood of 1949 (U.S. Geological Survey, 1952), the flood of April 1987 (Fontaine, 1987), and the flood of October 2005 (National Weather Service, 2005a, 2005b) are a few of the largest floods that are well documented for comparison to the 2011 flood. Additionally, the estimated 10-, 2-, 1-, and 0.2-percent AEP discharges at the streamgages in northwestern Massachusetts were compared with the AEPs in the FISs. Water-surface elevations of the 1-percent AEP flood determined from hydraulic models for recent (2015-16) hydraulic studies (Bent and others, 2015; Flynn and others, 2016; Lombard and Bent, 2015a,b) were compared with the water-surface elevations in the FISs.

\section{Previous Floods}

The August 28, 2011, tropical storm Irene peak flows and corresponding AEPs were compared with the following documented historic floods at three streamgages in the Deerfield and Hoosic River Basins: the floods of November 1927, March 1936, September 1938, New Year's Day 1949, April 1987, and October 2005. The streamgages that were in operation during most of these flood events were the Deerfield River at Charlemont, Mass., the Hoosic River at Adams, Mass., and the North Branch Hoosic River at North Adams, Mass.(01168500, 01331500, and 01332000, respectively; fig. 2). For the period of record through water year 2013, the annual peak discharges for the three streamgages are shown in figure 5. The comparisons for the peak discharges for these

A. Deerfield River at Charlemont (01168500)

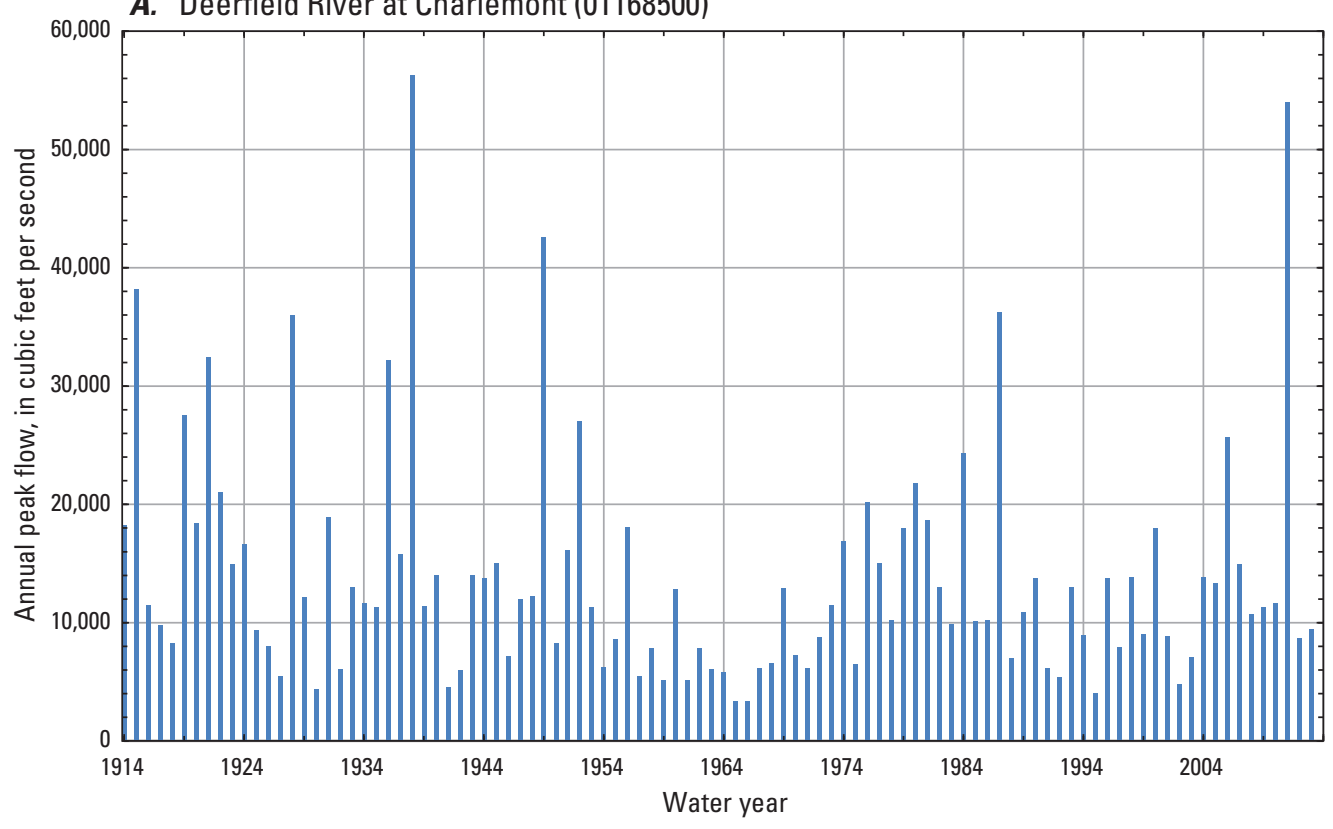

Figure 5. Annual peak flows through water year 2013 for streamgages $A$, Deerfield River at Charlemont, Massachusetts (01168500); B, Hoosic River at Adams, Mass. (01331500); and C, North Branch Hoosic River at North Adams, Mass. (01332000). A water year is the 12-month period beginning October 1 and ending September 30 and is designated by the year in which it ends. 
B. Hoosic River at Adams (01331500)

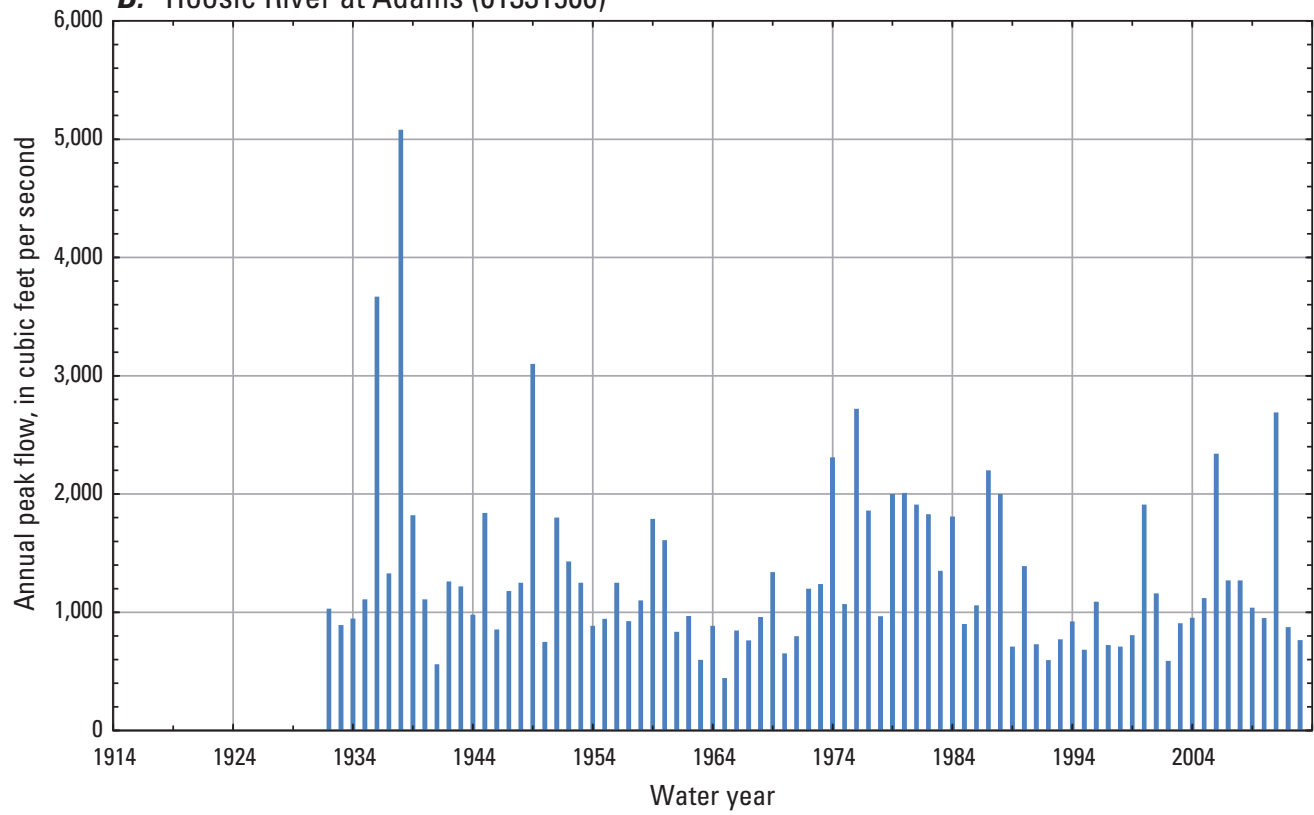

C. North Branch Hoosic River at North Adams (01332000)

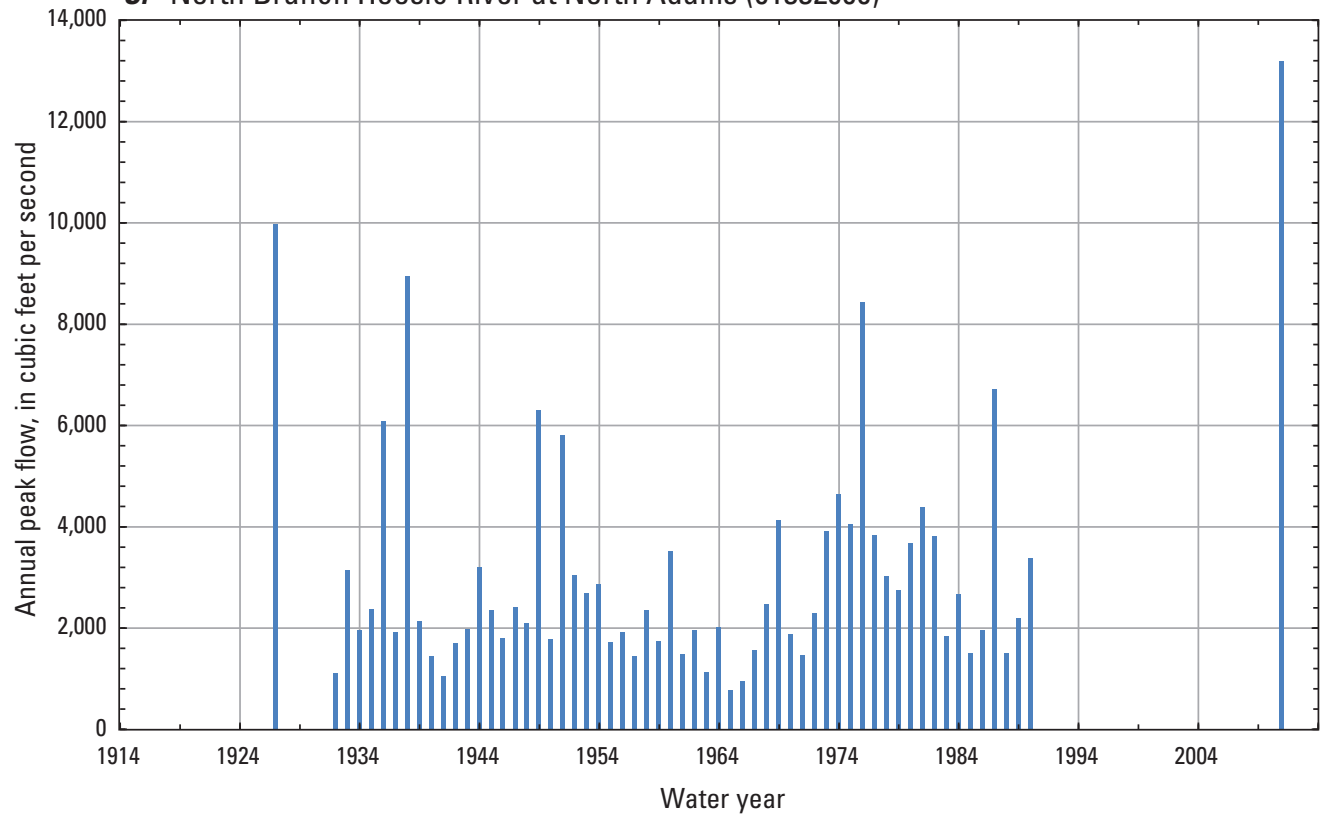

Figure 5. Annual peak flows through water year 2013 for streamgages $A$, Deerfield River at Charlemont, Massachusetts (01168500); B, Hoosic River at Adams, Mass. (01331500); and C, North Branch Hoosic River at North Adams, Mass. (01332000). A water year is the 12-month period beginning 0 ctober 1 and ending September 30 and is designated by the year in which it ends. -Continued 
historic floods and the discharges for the 2011 flood are shown in figure 5. Other floods are noticeable for the period of record for the three streamgages; however, the floods are not well documented — such as the flood of April 1976.

The November 1927 flood flows in northwestern Massachusetts generally were on November 4 and were the result of torrential rains on November 3-4 from a tropical storm that followed heavy rains on October 18 and 21 (Kinnison, 1930). During November 2-5, 1927, rainfall data in the Deerfield and Hoosic River Basins ranged from 4 to 8 inches, most of which fell on November 3-4. This flood event was only documented at two of the three streamgages - the Deerfield River at Charlemont, Mass., and the North Branch Hoosic River at North Adams, Mass. (01168500 and 01332000, respectively; figs. $5 \mathrm{~A}$ and $\mathrm{C}$ ) - because the Hoosic River at Adams, Mass., streamgage (01331500) had not been established yet.

The March 1936 flood flows in northwestern Massachusetts generally were on March 18 and were the result of generally between 6 and 8 inches of rainfall during March 9-22 in addition to the existing snowpack (Grover, 1937a,b). Before the flood, on March 9, 1936, the water content of snow on the ground in this area was generally from 5 to 6 inches. Total rainfall in this area during March 9-13 was from 2 to 3 inches of rainfall and during March 16-19 was from 2 to 5 inches. The combination of existing snowpack water content and the two rainfall events in March 1936 resulted in the peak flows on March 18 at the three streamgages in northwestern Massachusetts and across much of New England (Grover, 1937a,b). The peak flows for the three streamgages for March 18, 1936, are shown in comparison to the annual peak flows for each streamgage through water year 2013 (fig. 5).

The September 1938 flood flows in northwestern Massachusetts generally were on September 21 and were the result of about 2 inches of rainfall during September 12-16 followed by 8 to 10 inches of rainfall during September 17-21 (Paulsen, 1940). This rainfall includes 24-hour rainfall totals (ending at 6 p.m.) of about 1 to 3, 2 to 3, and 4 inches on September 19, 20, and 21, respectively. The September 21 rainfall was the result of a hurricane that passed from New England in the afternoon of that day. The hurricane's center went over Hartford, Connecticut (not shown), then along the Connecticut River in Massachusetts, and then passed over the intersection of Massachusetts, New Hampshire, and Vermont before heading northwest towards Lake Champlain (not shown) (Paulsen, 1940). The peak flows for the three streamgages for September 21, 1938, are shown in comparison to the annual peak flows for each streamgage through water year 2013 (fig. 5).

The New Year flood flows of 1949 generally were on December 31, 1948, in northwestern Massachusetts (U.S. Geological Survey, 1952). The flood flows were the result of between 3 to 10 inches of rainfall, which fell from December 29, 1948, through January 1, 1949, in the Deerfield and Hoosic River Basins. The peak flows for the three streamgages for December 31, 1948, are shown in comparison to the annual peak flows for each streamgage through water year 2013 (fig. 5).

The April 1987 flood flows in northwestern Massachusetts generally were on April 4-5. The flood flows were the results of about 1 to 3 inches of rainfall on March 30 to April 2 followed by about 3-9 inches of rainfall on April 4-8 (Fontaine, 1987). Additionally, a mid-March and end-ofMarch snow survey in the area reported snow depths from 9 to 11 inches and no snow, respectively. Thus, the combination of snowmelt and two rain storms during about a 3-week period resulted in the early April 1987 flood. The peak flows for the three streamgages for April 4-5, 1987, are shown in comparison to the annual peak flows for each streamgage through water year 2013 (fig. 5).

The October 2005 flood flows in northwestern Massachusetts generally were on October 8-9. The flood flows were the result of about 6 to 9 inches of rainfall (National Weather Service, 2005a) from the remnants of tropical storm Tammy (National Weather Service, 2005b). The peak flows for the two streamgages for October 8-9, 2005, are shown in comparison to the annual peak flows for each streamgage through water year 2013 (figs. 5A and $B$ ). The North Branch Hoosic River at North Adams, Mass., streamgage (01332000) could not be compared with the annual peak flows through water year 2013 because the streamgage was discontinued at the time of this flood.

\section{Published Flood Insurance Studies}

\section{Hydrology}

The discharges associated with the 10-, 2-, 1-, and 0.2 -percent AEPs at streamgages in the Deerfield and Hoosic River Basins and based on peak flow data through water year 2013 were compared with discharges in the FISs (table 3). The FISs for selected river reaches in the Deerfield River Basin are for the towns of Buckland (Federal Emergency Management Agency, 1979a), Charlemont (Federal Emergency Management Agency, 1980a), Colrain (Federal Emergency Management Agency, 1980b), Conway (Federal Emergency Management Agency, 1979b), Deerfield (Federal Emergency Management Agency, 1980c), Greenfield (Federal Emergency Management Agency, 1980d), and Shelburne (Federal Emergency Management Agency, 1980e) and in the Hoosic River Basin are for the city of North Adams (Federal Emergency Management Agency, 1981) and the towns of Adams (Federal Emergency Management Agency, 1983a) and Williamstown (Federal Emergency Management Agency, 1983b). The discharges computed for the AEPs at the streamgages for this study had an additional 30-35 years of peak flow data compared with the discharges in the FISs, except at the two discontinued streamgages - the Deerfield River near Rowe, Mass., and the North Branch Hoosic 


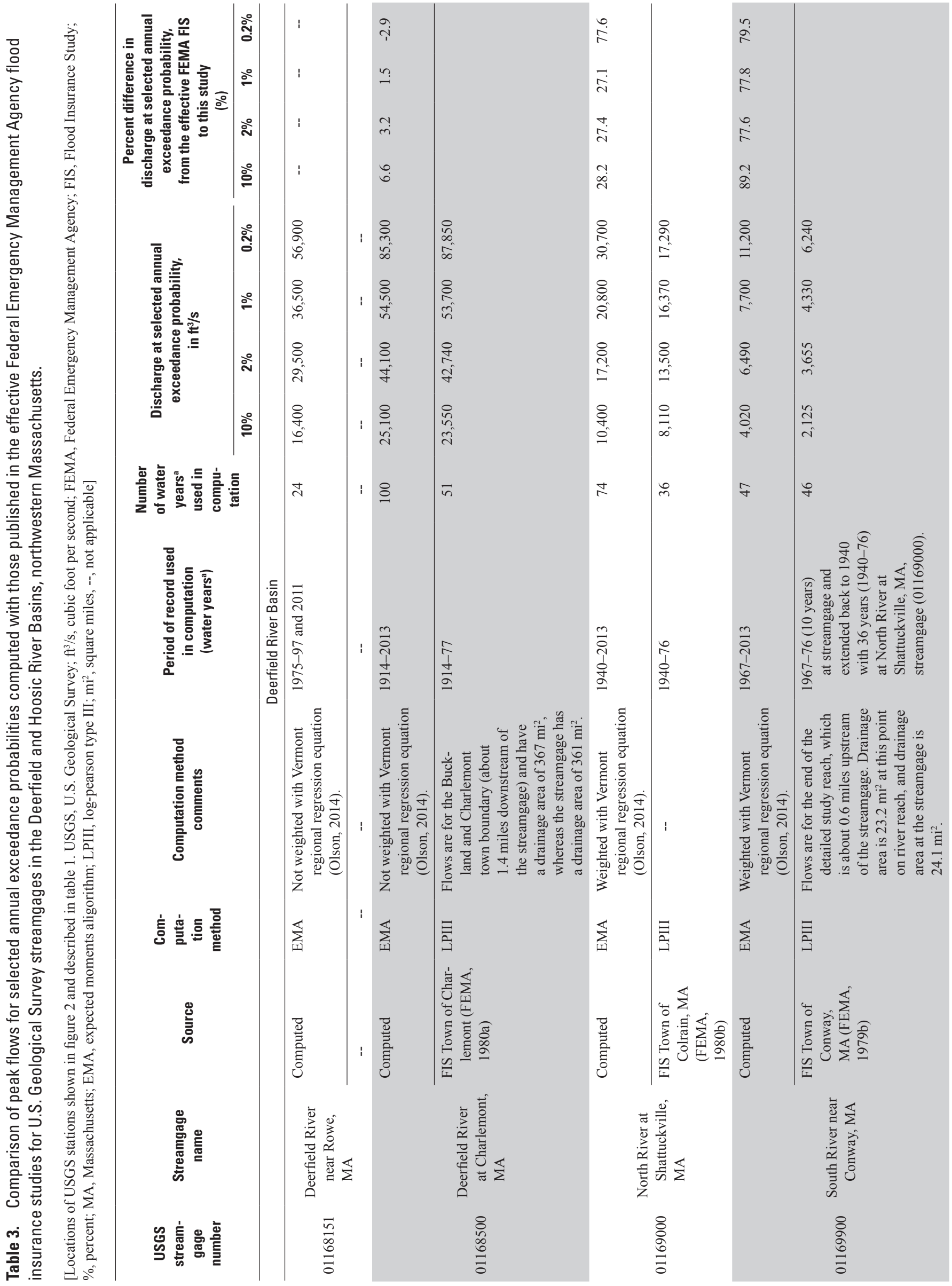




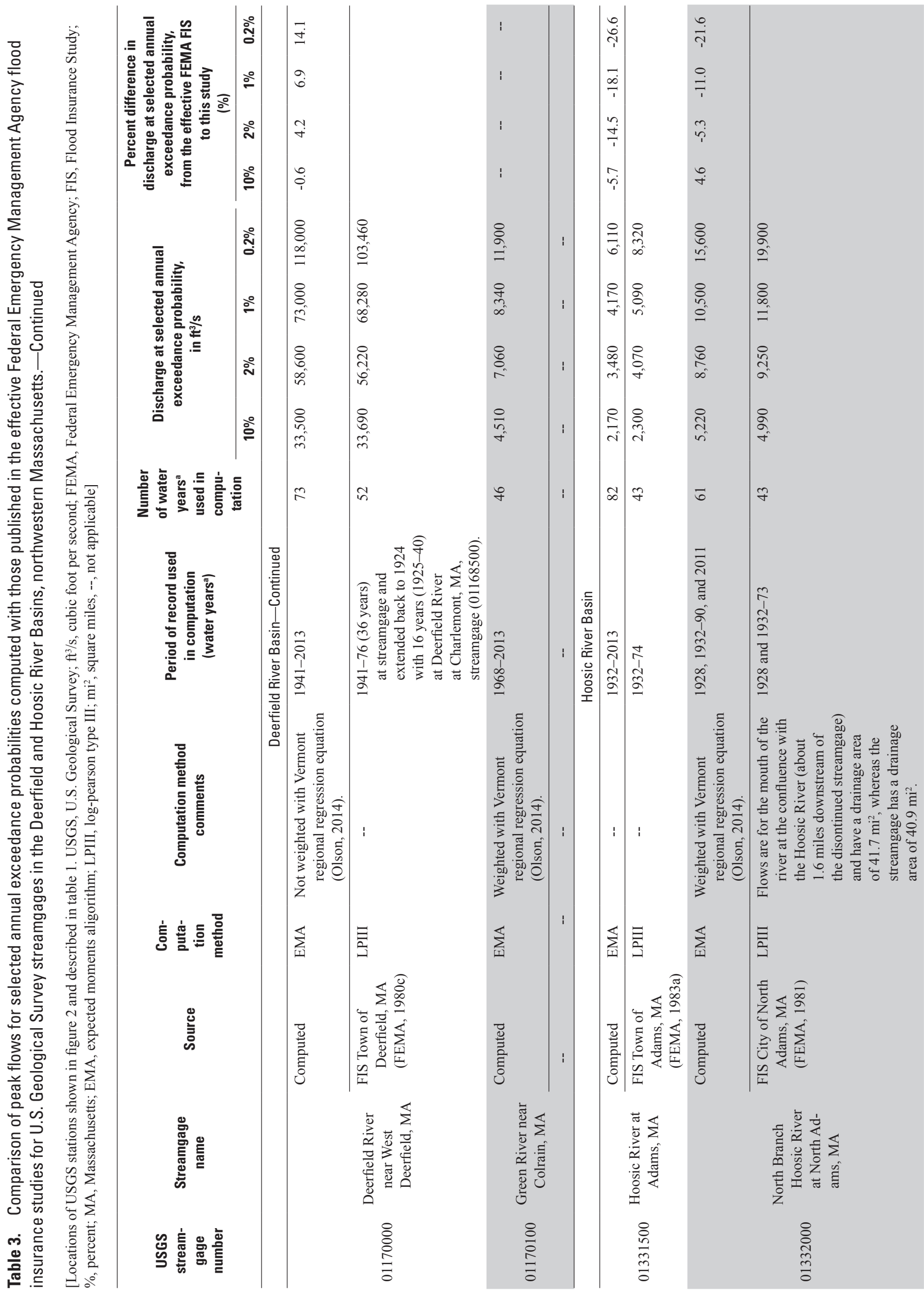




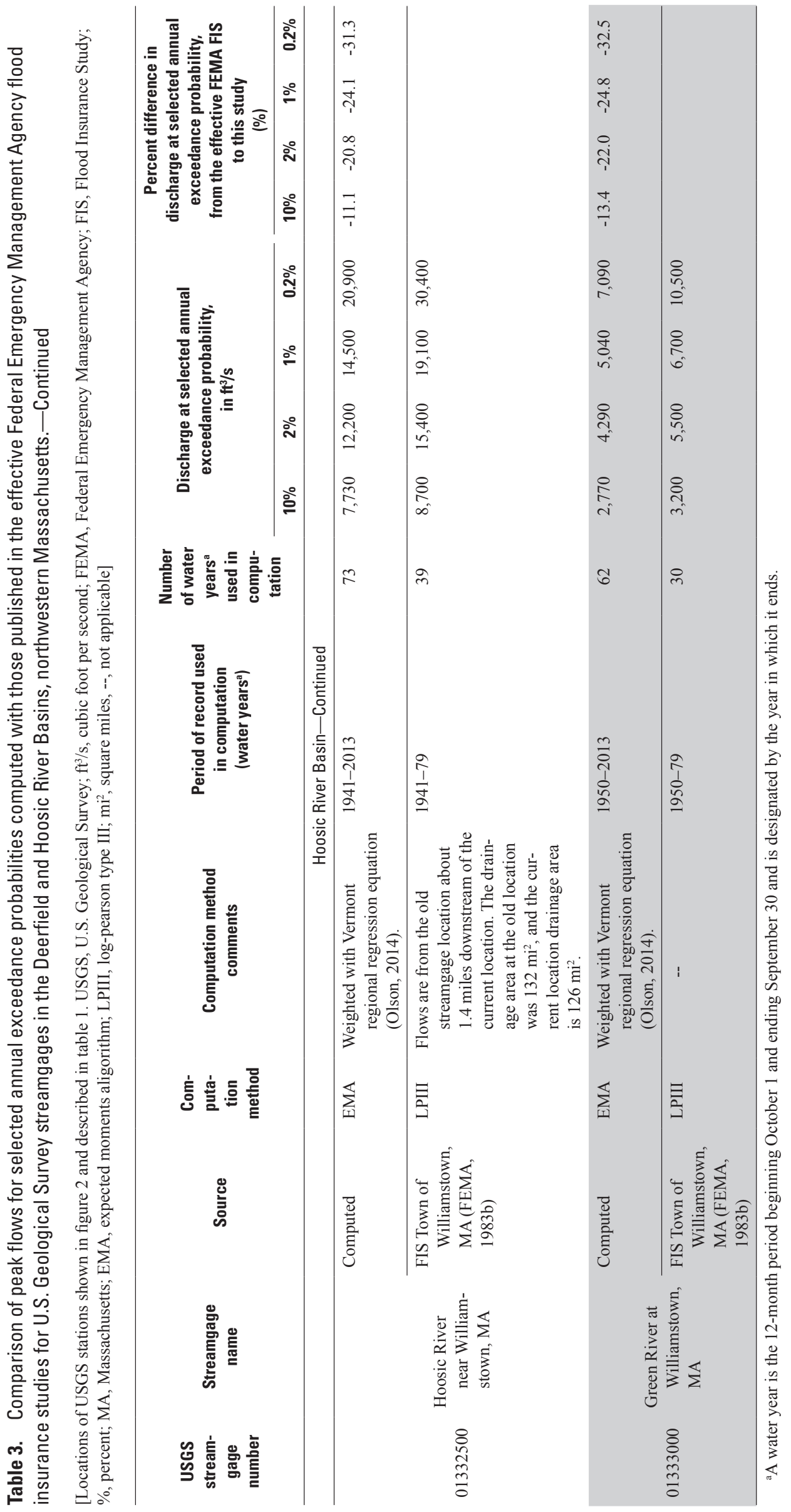


River at North Adams, Mass. (01168151 and 01332000, respectively; fig. 2).

For streamgages in the Deerfield River Basin, the computed 10-, 2-, 1-, and 0.2-percent AEP discharges generally were higher than discharges in the FISs (table 3). At the two streamgages on the main stem of the Deerfield River, the Deerfield River at Charlemont, Mass., and the Deerfield River near West Deerfield, Mass. (01168500 and 01170000, respectively; fig. 2), the computed AEP discharges had differences that ranged from about 3 percent lower to 14 percent higher than discharges in the FISs. The largest differences between the AEP discharges computed and those in the FISs in the Deerfield River Basin were at the two streamgages on tributaries to the Deerfield River, the North River at Shattuckville, Mass., and the South River near Conway, Mass. (01169000 and 01169900, respectively; fig. 2). Estimated AEP discharges at these two streamgages ranged from about 27 to 89 percent higher than the FISs.

In the Hoosic River Basin (fig. 2), the 10-, 2-, 1-, and 0.2-percent AEP discharges computed for the four streamgages ranged from about 33 percent lower to 5 percent higher than discharges in the FISs (table 3). Only the 4-percent AEP discharge at the North Branch Hoosic River at North Adams, Mass., streamgage (01332000) indicated an increase (4.6 percent); all other AEP discharges computed at the four streamgages decreased compared with discharges in the FISs (table 3).

The most likely reason for the percent differences between the 10-, 2-, 1-, and 0.2-percent AEP discharges seen on the tributaries to the Deerfield River and in the Hoosic River Basin is the availability of an additional 30-35 years of annual peak flows for AEP analyses. The large percent differences for the North River at Shattuckville, Mass., and the South River near Conway, Mass., streamgages (01169000 and 01169900, respectively) may be that the annual peak flows for the streamgages indicated a significant ( $p$-value less than or equal to 0.05 ) positive trend over their period of record. The other streamgages in the study area did not indicate a significant positive or negative trend in annual peak flows over their period of record. The percent differences also could be related to land-use changes - such as any increases in greater area of urban land uses because of increased medium- to high-density areas of residential housing, commercial and industrial development, and roads and highways in the river basins.

\section{Water-Surface Elevations}

The water-surface elevations of the 1-percent AEP discharge were simulated from hydraulic models for sections of the Deerfield River (Lombard and Bent, 2015b), Green River (Flynn and others, 2016), North River (Bent and others, 2015), and Hoosic River (Lombard and Bent, 2015a). The hydraulic modeling for these studies was completed using the U.S. Army Corps of Engineer (USACE) Hydrologic Engineering Center-River Analysis System (HEC-RAS) model. The simulated water-surface elevations of the 1-percent AEP discharge from these recent (2015-16) studies were compared with those published in the FISs at select locations in the coinciding river reaches. The simulated water-surface elevations of the 1-percent AEP discharge from these recent studies is nonregulatory and does not supersede those in the published FISs. The FIS water-surface elevations were converted from National Geodetic Vertical Datum of 1929 (NGVD 29) to NAVD 88 by using the average conversion from the latitudes and longitudes of a river reach for about three to five locations depending on how much the conversion values differed along the river reach. Generally, the conversion values only differed a few hundreds of a foot along a river reach. The conversion values were determined by using the National Geodetic Survey VERTCON (orthometric height conversion program; http://www.ngs.noaa.gov/cgibin/VERTCON/vert_con.prl; Gilbert, 1999). If the location distances for the FIS water-surface elevations were in miles, the distance was converted into feet from the starting location of the river reach, which was generally the confluence with another river.

The simulated water-surface elevations of the 1-percent AEP discharge for the Deerfield River determined from the HEC-RAS hydraulic model developed by Lombard and Bent (2015b) were compared with those in the FISs for the (1) town of Deerfield (1980c) from the confluence of the Connecticut River upstream to the town boundary with Conway, (2) town of Shelburne (1980e) from just downstream from dam number 3 upstream to State Route 2, and (3) town of Charlemont (1980a) from dam number 4 upstream to the railroad bridge just downstream from the Cold River tributary. The comparisons of the two water-surface elevations were made at 25 selected locations generally upstream and downstream from bridges, dams, and major tributaries (table 4). The simulated water-surface elevations of the 1-percent AEP discharge (Lombard and Bent, 2015b) averaged $2.2 \mathrm{ft}$ higher (median $1.5 \mathrm{ft}$ higher) than the water-surface elevations from the FISs. The difference between 1-percent AEP discharge water-surface elevations in Lombard and Bent (2015b) and the FISs ranged from $2.0 \mathrm{ft}$ lower to $7.3 \mathrm{ft}$ higher (table 4).

The simulated water-surface elevations of the 1-percent AEP discharge for the Green River determined from the HEC-RAS hydraulic model developed by Flynn and others (2016) were compared with those in the FIS for the town of Greenfield (1980d) from the confluence with the Deerfield River upstream from the town boundary between Greenfield, Colrain, and West Leyden. The water-surface elevations were compared at 23 selected locations, generally upstream and downstream from bridges, dams, and major tributaries (table 5). The simulated water-surface elevations of the 1-percent AEP discharge (Flynn and others, 2016) averaged $2.3 \mathrm{ft}$ higher (median $2.4 \mathrm{ft}$ higher) than the FIS water-surface elevations. The difference between 1-percent AEP discharge water-surface elevations in Flynn and others (2016) and the FIS ranged from $6.1 \mathrm{ft}$ lower to $6.1 \mathrm{ft}$ higher (table 5).

The simulated water-surface elevations of the 1-percent AEP discharge for the North River determined from the 
Table 4. Comparison of the simulated water-surface elevations for the Deerfield River for the 1-percent annual exceedance probability discharge determined by Lombard and Bent (2015b) with those published in the effective Federal Emergency Management Agency flood insurance studies.

[Cells shaded gray indicate locations that can be affected by backwater from the Connecticut River, but the water-surface elevations presented are not backwater elevations. Streamgage locations shown on figure 2 and described in table 1. FIS, flood insurance study; FEMA, Federal Emergency Management Agency; ft, foot; USACE, U.S. Army Corps of Engineers; HEC-RAS, Hydrologic Engineering Centers-River Analysis System; NAVD 88, North American Vertical Datum of 1988; DS, downstream; US, upstream; Rt., Route; Rd., Road; USGS, U.S. Geological Survey; MA, Massachusetts; St., Street; NGVD 29, National Geodetic Vertical Datum of 1929]

\begin{tabular}{|c|c|c|c|c|c|}
\hline \multirow[t]{2}{*}{ Description of location } & $\begin{array}{c}\text { FIS towns } \\
\text { of Deerfield } \\
\text { (FEMA, 1980c), } \\
\text { Shelburne } \\
\text { (FEMA, 1980e), } \\
\text { and Charlemont, } \\
\text { Massachusetts } \\
\text { (FEMA, 1980a) }\end{array}$ & $\begin{array}{c}\text { Lombard and } \\
\text { Bent (2015b) } \\
\text { USACE } \\
\text { HEC-RAS } \\
\text { hydraulic } \\
\text { model }\end{array}$ & $\begin{array}{c}\text { FIS towns } \\
\text { of Deerfield } \\
\text { (FEMA, 1980c), } \\
\text { Shelburne } \\
\text { (FEMA, 1980e), } \\
\text { and Charlemont } \\
\text { (FEMA, 1980a) }\end{array}$ & $\begin{array}{c}\text { Lombard and } \\
\text { Bent (2015b) } \\
\text { USACE } \\
\text { HEC-RAS } \\
\text { hydraulic } \\
\text { model }\end{array}$ & \multirow{2}{*}{$\begin{array}{l}\text { Difference in } \\
\text { FIS and } \\
\text { Lombard and } \\
\text { Bent (2015b) } \\
\text { USACE } \\
\text { HEC-RAS hy- } \\
\text { draulic model } \\
\text { water-surface } \\
\text { elevation } \\
\text { (ft) }^{c}\end{array}$} \\
\hline & $\begin{array}{l}\text { Location from } \\
\text { confluence with } \\
\text { Connecticut } \\
\text { River } \\
\text { (ft) }\end{array}$ & $\begin{array}{l}\text { Location from } \\
\text { confluence with } \\
\text { Connecticut } \\
\text { River } \\
\text { (ft) }\end{array}$ & $\begin{array}{l}\text { Water-surface } \\
\text { elevation- } \\
\text { converted to } \\
\text { NAVD } 88 \\
\text { (ft) }\end{array}$ & $\begin{array}{l}\text { Water- } \\
\text { surface } \\
\text { elevation- } \\
\text { NAVD } 88 \\
\text { (ft) }\end{array}$ & \\
\hline Confluence with Connecticut River & 407 & 637 & 122.4 & 126.6 & 4.2 \\
\hline $\begin{array}{l}\text { DS from railroad bridge, Deerfield and Greenfield, } \\
\text { MA }\end{array}$ & 2,344 & 1,618 & 130.7 & 130.8 & 0.1 \\
\hline US from railroad bridge, Deerfield and Greenfield & -- & 2,240 & -- & 132.8 & -- \\
\hline DS from railroad bridge, Deerfield and Greenfield & 5,914 & 5,111 & 132.6 & 135.9 & 3.4 \\
\hline US from failroad bridge, Deerfield and Greenfield & -- & 5,737 & -- & 138.2 & -- \\
\hline DS from State Rt. 5 and 10, Deerfield and Greenfield & -- & 5,737 & -- & 138.2 & -- \\
\hline US from State Rt. 5 and 10, Deerfield and Greenfield & 6,283 & 6,494 & 133.9 & 140.1 & 6.3 \\
\hline DS from U.S. Interstate I-91 Northbound, Deerfield & 39,700 & 38,887 & 154.4 & 153.5 & -0.8 \\
\hline US from U.S. Interstate I-91 Northbound, Deerfield & 40,870 & 40,706 & 157.7 & 159.6 & 2.0 \\
\hline DS from Stillwater Bridge, Upper Rd., Deerfield & 42,400 & 41,800 & 157.7 & 161.3 & 3.7 \\
\hline US from Stillwater Bridge, Upper Rd., Deerfield & 43,670 & 42,686 & 161.6 & 168.8 & 7.3 \\
\hline $\begin{array}{l}\text { USGS streamgage Deerfield River near West } \\
\text { Deerfield, MA (01170000) }\end{array}$ & 50,480 & 50,623 & 173.6 & 178.7 & 5.1 \\
\hline Confluence with South River & 52,540 & 51,628 & 177.9 & 181.4 & 3.5 \\
\hline DS from Dam \#3, Buckland and Shelburne, MA & -- & 88,700 & -- & 360.3 & -- \\
\hline US from Dam \#3, Buckland and Shelburne & 89,340 & 89,313 & 410.2 & 411.7 & 1.5 \\
\hline $\begin{array}{l}\text { DS from steel bridge, Bridge St., Buckland and } \\
\text { Shelburne }\end{array}$ & 89,710 & 89,796 & 411.1 & 411.8 & 0.7 \\
\hline $\begin{array}{l}\text { US from Bridge of Flowers, Buckland and } \\
\text { Shelburne }\end{array}$ & 90,290 & 90,699 & 414.7 & 420.6 & 5.9 \\
\hline
\end{tabular}


Table 4. Comparison of the simulated water-surface elevations for the Deerfield River for the 1-percent annual exceedance probability discharge determined by Lombard and Bent (2015b) with those published in the effective Federal Emergency Management Agency flood insurance studies.-Continued

[Cells shaded gray indicate locations that can be affected by backwater from the Connecticut River, but the water-surface elevations presented are not backwater elevations. Streamgage locations shown on figure 2 and described in table 1. FIS, flood insurance study; FEMA, Federal Emergency Management Agency; ft, foot; USACE, U.S. Army Corps of Engineers; HEC-RAS, Hydrologic Engineering Centers-River Analysis System; NAVD 88, North American Vertical Datum of 1988; DS, downstream; US, upstream; Rt., Route; Rd., Road; USGS, U.S. Geological Survey; MA, Massachusetts; St., Street; NGVD 29, National Geodetic Vertical Datum of 1929]

\begin{tabular}{|c|c|c|c|c|c|}
\hline \multirow[t]{2}{*}{ Description of location } & $\begin{array}{c}\text { FIS towns } \\
\text { of Deerfield } \\
\text { (FEMA, 1980c), } \\
\text { Shelburne } \\
\text { (FEMA, 1980e), } \\
\text { and Charlemont, } \\
\text { Massachusetts } \\
\text { (FEMA, 1980a) }\end{array}$ & $\begin{array}{c}\text { Lombard and } \\
\text { Bent (2015b) } \\
\text { USACE } \\
\text { HEC-RAS } \\
\text { hydraulic } \\
\text { model }\end{array}$ & $\begin{array}{c}\text { FIS towns } \\
\text { of Deerfield } \\
\text { (FEMA, 1980c), } \\
\text { Shelburne } \\
\text { (FEMA, 1980e), } \\
\text { and Charlemont } \\
\text { (FEMA, 1980a) }\end{array}$ & $\begin{array}{c}\text { Lombard and } \\
\text { Bent (2015b) } \\
\text { USACE } \\
\text { HEC-RAS } \\
\text { hydraulic } \\
\text { model }\end{array}$ & \multirow{2}{*}{$\begin{array}{l}\text { Difference in } \\
\text { FIS and } \\
\text { Lombard and } \\
\text { Bent (2015b) } \\
\text { USACE } \\
\text { HEC-RAS hy- } \\
\text { draulic model } \\
\text { water-surface } \\
\text { elevation } \\
\text { (ft) }^{c}\end{array}$} \\
\hline & $\begin{array}{l}\text { Location from } \\
\text { confluence with } \\
\text { Connecticut } \\
\text { River } \\
\text { (ft) }\end{array}$ & $\begin{array}{l}\text { Location from } \\
\text { confluence with } \\
\text { Connecticut } \\
\text { River } \\
\text { (ft) }\end{array}$ & $\begin{array}{l}\text { Water-surface } \\
\text { elevation- } \\
\text { converted to } \\
\text { NAVD } 88 \\
\text { (ft })^{\mathrm{b}}\end{array}$ & $\begin{array}{l}\text { Water- } \\
\text { surface } \\
\text { elevation- } \\
\text { NAVD } 88 \\
\text { (ft) }\end{array}$ & \\
\hline DS from State Rt. 2 bridge, Buckland and Shelburne & 93,390 & 93,333 & 422.2 & 422.4 & 0.2 \\
\hline US from State Rt. 2 bridge, Buckland and Shelburne & 93,500 & 94,300 & 422.9 & 423.6 & 0.7 \\
\hline DS from Dam \#4, Buckland and Charlemont, MA & -- & 103,761 & -- & 446.2 & -- \\
\hline US from Dam \#4, Buckland and Charlemont & 104,020 & 104,499 & 480.0 & 486.0 & 6.0 \\
\hline $\begin{array}{l}\text { DS from State Rt. } 2 \text { bridge, Buckland and } \\
\text { Charlemont }\end{array}$ & 104,440 & 104,684 & 481.1 & 486.2 & 5.1 \\
\hline $\begin{array}{l}\text { US from State Rt. } 2 \text { bridge, Buckland and } \\
\text { Charlemont }\end{array}$ & 104,740 & 105,234 & 481.1 & 486.1 & 5.0 \\
\hline $\begin{array}{l}\text { USGS streamgage Deerfield River at Charlemont, } \\
\text { MA (01168500) }\end{array}$ & 135,850 & 135,620 & 537.8 & 536.3 & -1.5 \\
\hline DS from State Rt. 8A bridge, Charlemont & 143,620 & 143,693 & 554.0 & 552.0 & -2.0 \\
\hline US from State Rt. 8A bridge, Charlemont & 143,830 & 144,321 & 554.6 & 553.1 & -1.5 \\
\hline DS from State Rt. 2 Bridge, Charlemont & 152,490 & 152,572 & 572.5 & 573.4 & 0.9 \\
\hline US from State Rt. 2 Bridge, Charlemont & 152,920 & 153,480 & 573.6 & 575.0 & 1.4 \\
\hline DS from railroad bridge, Charlemont & 157,660 & 158,173 & 593.6 & 591.8 & -1.8 \\
\hline \multirow[t]{6}{*}{ US from railroad bridge, Charlemont } & 157,870 & 158,527 & 597.4 & 596.7 & -0.7 \\
\hline & & & \multicolumn{2}{|c|}{ Number of observations } & 25 \\
\hline & & & \multicolumn{2}{|c|}{ Minimum } & -2.0 \\
\hline & & & \multicolumn{2}{|c|}{ Maximum } & 7.3 \\
\hline & & & \multicolumn{2}{|l|}{ Average } & 2.2 \\
\hline & & & \multicolumn{2}{|l|}{ Median } & 1.5 \\
\hline
\end{tabular}

\footnotetext{
${ }^{a}$ The FIS location in miles from confluence with Connecticut River was converted to feet.

${ }^{\text {b}}$ The average conversion value from NGVD 29 to NAVD 88 for the FIS water-surface elevations was $-0.55 \mathrm{ft}$. The conversion was done using the National Geodetic Service VERTCON orthometric height conversion program (Gilbert, 1999) at http://www.ngs.noaa.gov/cgi-bin/VERTCON/vert_con.prl.

${ }^{\mathrm{c}}$ The difference may not be exact to the tenth of a foot because of rounding of FIS and hydraulic model values.
} 
Table 5. Comparison of the water-surface elevations for the Green River for the 1-percent annual exceedance probability discharge determined by Flynn and others (2016) with those published in the effective Federal Emergency Management Agency flood insurance study.

[Cells shaded gray indicate locations that can be affected by backwater from the Deerfield and Connecticut Rivers, but the water-surface elevations presented are not backwater elevations. Streamgage locations shown on figure 2 and described in table 1. FIS, flood insurance study; FEMA, Federal Emergency Management Agency; ft, foot; USACE, U.S. Army Corps of Engineers; HEC-RAS, Hydrologic Engineering Centers-River Analysis System; NAVD 88, North American Vertical Datum of 1988; DS, downstream; US, upstream; St., Street; Rt., Route; Rd., Road; NGVD 29, National Geodetic Vertical Datum of 1929]

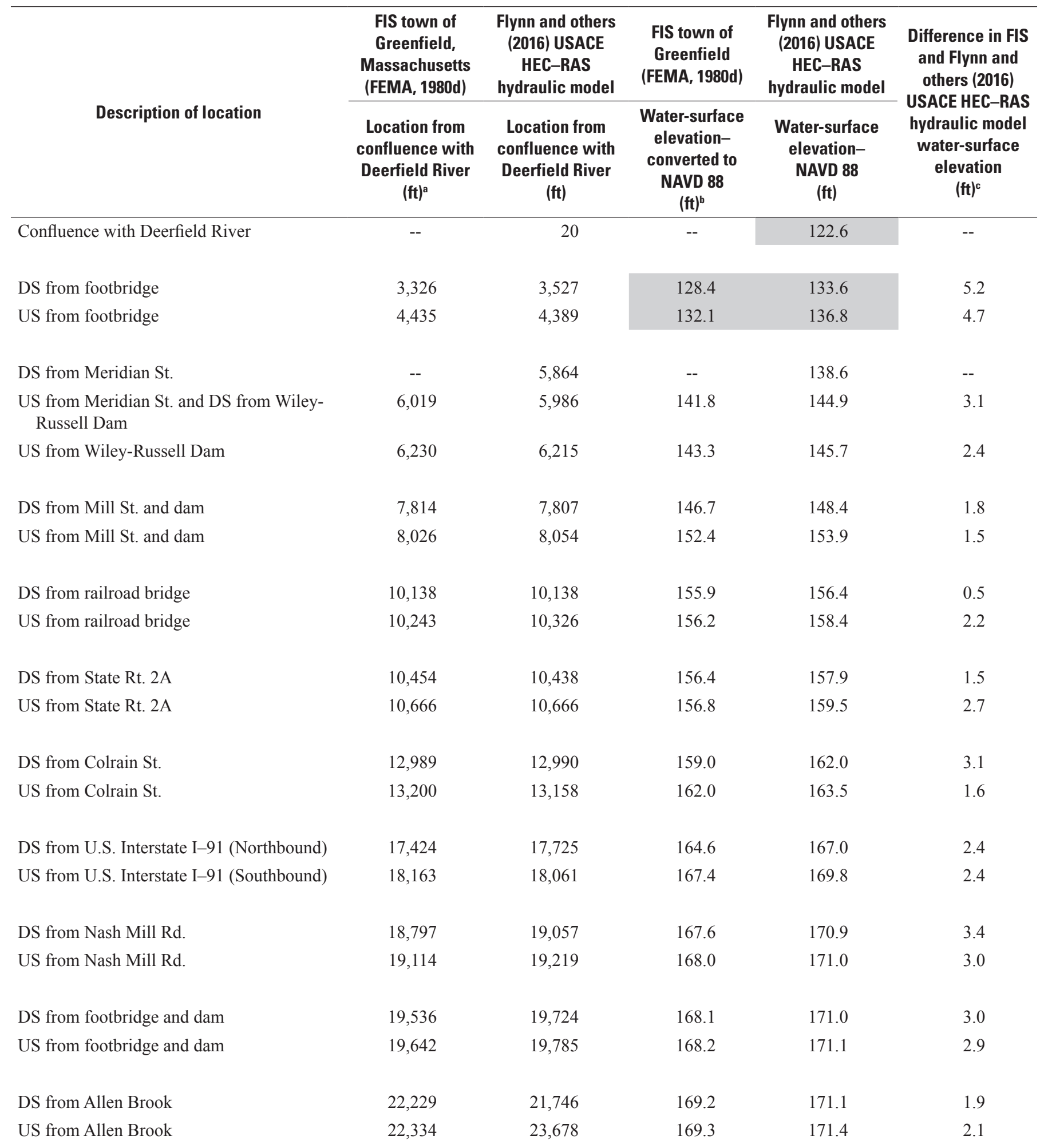


Table 5. Comparison of the water-surface elevations for the Green River for the 1-percent annual exceedance probability discharge determined by Flynn and others (2016) with those published in the effective Federal Emergency Management Agency flood insurance study.-Continued

[Cells shaded gray indicate locations that can be affected by backwater from the Deerfield and Connecticut Rivers, but the water-surface elevations presented are not backwater elevations. Streamgage locations shown on figure 2 and described in table 1. FIS, flood insurance study; FEMA, Federal Emergency Management Agency; ft, foot; USACE, U.S. Army Corps of Engineers; HEC-RAS, Hydrologic Engineering Centers-River Analysis System; NAVD 88, North American Vertical Datum of 1988; DS, downstream; US, upstream; St., Street; Rt., Route; Rd., Road; NGVD 29, National Geodetic Vertical Datum of 1929]

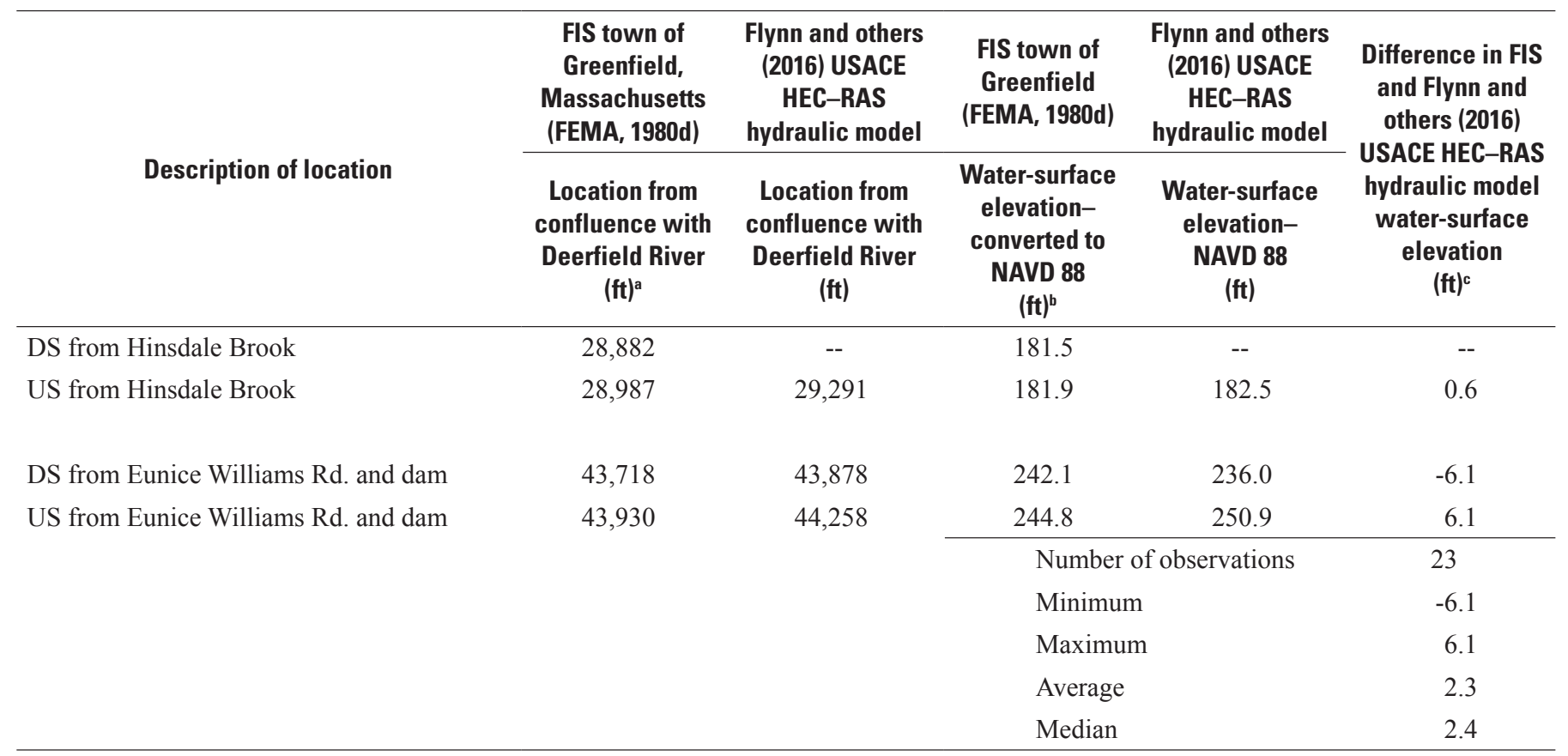

${ }^{a}$ The FIS location in miles from confluence with Deerfield River was converted to feet.

${ }^{\text {b}}$ The average conversion value from NGVD 29 to NAVD 88 for the FIS water-surface elevations was $-0.54 \mathrm{ft}$. The conversion was done using the National Geodetic Service VERTCON orthometric height conversion program (Gilbert, 1999) at http://www.ngs.noaa.gov/cgi-bin/VERTCON/vert_con.prl.

${ }^{\mathrm{c}}$ The difference may not be exact to the tenth of a foot because of rounding of FIS and hydraulic model values.

HEC-RAS hydraulic model developed by Bent and others (2015) were compared with those of the FIS for the town of Colrain (1980b) from the confluence with the Deerfield River upstream to the confluence of the East Branch North River and West Branch North River. The water-surface elevations were compared at seven selected locations generally at locations upstream and downstream from bridges and dams (table 6). The simulated water-surface elevations of the 1-percent AEP discharge (Bent and others, 2015) averaged $0.3 \mathrm{ft}$ higher (median $1.7 \mathrm{ft}$ higher) than the FIS water-surface elevations. The difference between 1-percent AEP discharge water-surface elevations in Bent and others (2015) and the FIS ranged from $7.6 \mathrm{ft}$ lower to $3.7 \mathrm{ft}$ higher. The $7.6 \mathrm{ft}$ lower water-surface elevation (Bent and others, 2015) was upstream from Barnhardt dam (just downstream from the confluence of the East Branch North River and West Branch North River), which was breached during tropical storm Irene and currently (2016) has not been repaired. In the model of a recent study (Bent and others, 2015), the breached dam does not provide storage and, consequently, indicates that the model has a lower water-surface elevation at this location compared with the water-surface elevation in the FIS, which has the dam with no breach.

The simulated water-surface elevations of the 1-percent AEP discharge for the Hoosic River determined from the HEC-RAS hydraulic model developed by Lombard and Bent (2015a) were compared with those of the FISs for the town of Williamstown (1983b) and the city of North Adams (1981) from the Massachusetts-Vermont State border in Williamstown upstream to the confluence with the North Branch Hoosic River in the City of North Adams. The water-surface elevations were compared at 26 selected locations generally upstream and downstream from bridges, dams, and major tributaries (table 7). The simulated water-surface elevations of the 1-percent AEP discharge (Lombard and Bent, 2015a) averaged $0.7 \mathrm{ft}$ higher (median $0.6 \mathrm{ft}$ higher) than the FISs' water-surface elevations. The difference between 1-percent AEP discharge water-surface elevations in Lombard and Bent (2015a) and the FISs ranged from $2.7 \mathrm{ft}$ lower to $7.2 \mathrm{ft}$ higher (table 7). 
Table 6. Comparison of the water-surface elevations for the North River for the 1-percent annual exceedance probability discharge determined by Bent and others (2015) with those published in the effective Federal Emergency Management Agency flood insurance study.

[Streamgage locations shown on figure 2 and described in table 1. FIS, flood insurance study; FEMA, Federal Emergency Management Agency; ft, foot; USACE, U.S. Army Corps of Engineers; HEC-RAS, Hydrologic Engineering Centers-River Analysis System; NAVD 88, North American Vertical Datum of 1988; USGS, U.S. Geological Survey; MA, Massachusetts; DS, downstream; US, upstream; Rt., Route; Rd., Road; NGVD 29, National Geodetic Vertical Datum of 1929]

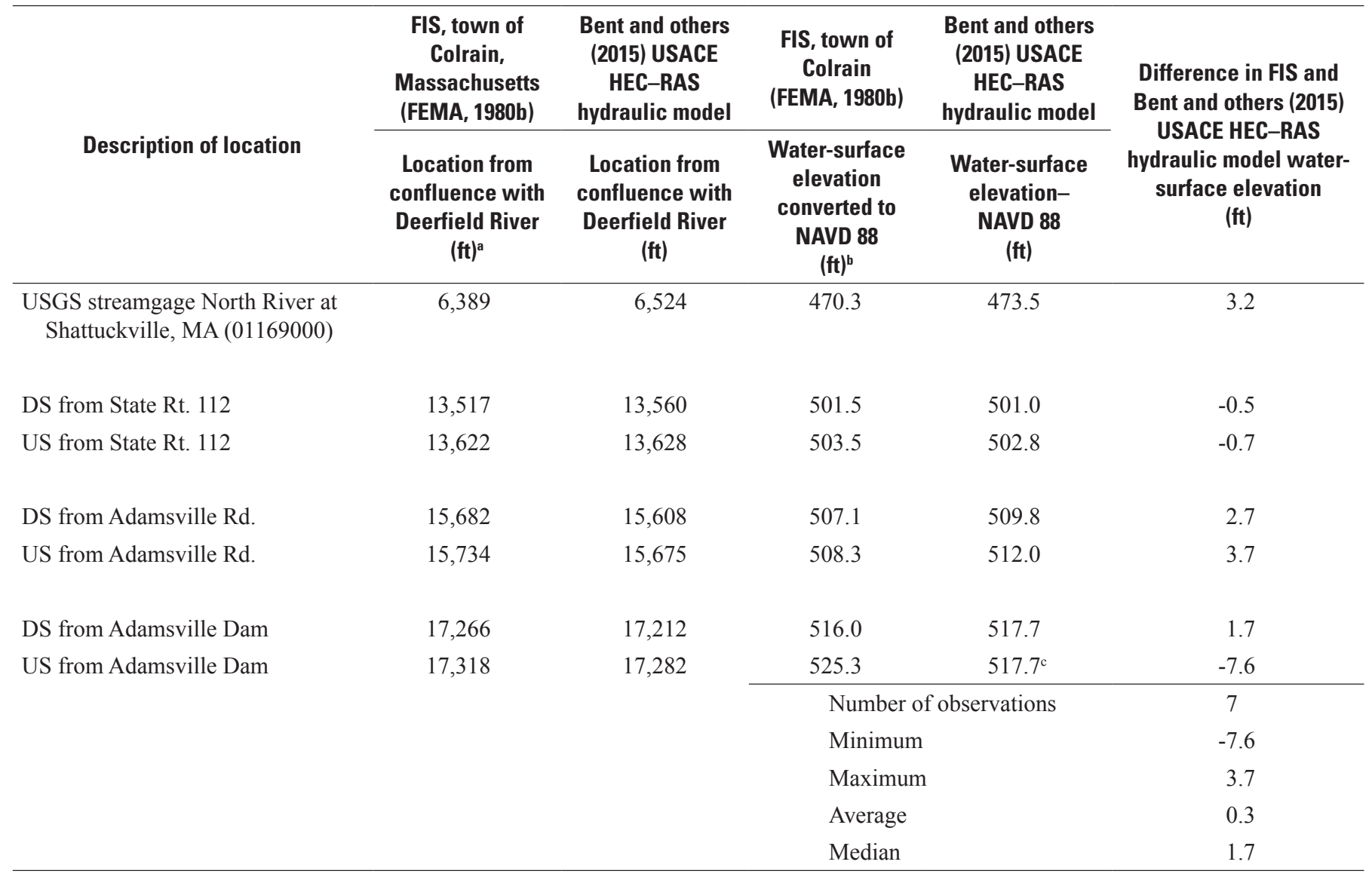

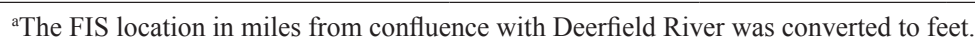

${ }^{\text {b}}$ The average conversion value from NGVD 29 to NAVD 88 for the FIS water-surface elevations was $-0.48 \mathrm{ft}$. The conversion was done using the National Geodetic Service VERTCON orthometric height conversion program (Gilbert, 1999) at http://www.ngs.noaa.gov/cgi-bin/VERTCON/vert_con.prl.

${ }^{\mathrm{c} E l e v a t i o n}$ of water-surface may be affected by breached section of dam due to tropical storm Irene August 28, 2011. 
Table 7. Comparison of the water-surface elevations for the Hoosic River for the 1-percent annual exceedance probability discharge determined by Lombard and Bent (2015a) with those published in the effective Federal Emergency Management Agency flood insurance studies.

[Streamgage locations shown on figure 2 and described in table 1. FIS, flood insurance study; FEMA, Federal Emergency Management Agency; ft, foot; USACE, U.S. Army Corps of Engineers; HEC-RAS, Hydrologic Engineering Centers-River Analysis System; NAVD 88, North American Vertical Datum of 1988; DS, downstream; US, upstream; Rt., Route; Rd., Road; Ave., Avenue; USGS, U.S. Geological Survey; MA, Massachusetts; St., Street; NGVD 29, National Geodetic Vertical Datum of 1929]

\begin{tabular}{|c|c|c|c|c|c|}
\hline \multirow[t]{2}{*}{ Description of location } & $\begin{array}{l}\text { FIS, town of } \\
\text { Williamstown } \\
\text { (FEMA, 1983b) } \\
\text { and city of } \\
\text { North Adams, } \\
\text { Massachusetts } \\
\text { (FEMA, 1981) }\end{array}$ & $\begin{array}{l}\text { Lombard and } \\
\text { Bent (2015a) } \\
\text { USACE } \\
\text { HEC-RAS hy- } \\
\text { draulic model }\end{array}$ & $\begin{array}{l}\text { FIS, town of } \\
\text { Williamstown } \\
\text { (FEMA, 1983b) } \\
\text { and city of } \\
\text { North Adams } \\
\text { (FEMA, 1981) }\end{array}$ & $\begin{array}{c}\text { Lombard and } \\
\text { Bent (2015a) } \\
\text { USACE } \\
\text { HEC-RAS } \\
\text { hydraulic } \\
\text { model }\end{array}$ & \multirow{2}{*}{$\begin{array}{c}\text { Difference } \\
\text { between FIS } \\
\text { and Lombard } \\
\text { and Bent (2015a) } \\
\text { USACE HEC-RAS } \\
\text { hydraulic model } \\
\text { water-surface } \\
\text { elevation } \\
\text { (ft) }\end{array}$} \\
\hline & $\begin{array}{l}\text { Location from } \\
\text { Massachusetts- } \\
\text { Vermont State } \\
\text { border } \\
\text { (ft) }\end{array}$ & $\begin{array}{l}\text { Location from } \\
\text { Massachusetts- } \\
\text { Vermont State } \\
\text { border } \\
\text { (ft) }\end{array}$ & $\begin{array}{l}\text { Water-surface } \\
\text { elevation, } \\
\text { converted to } \\
\text { NAVD } 88 \\
\text { (ft) }\end{array}$ & $\begin{array}{l}\text { Water-surface } \\
\text { elevation, } \\
\text { NAVD } 88 \\
\text { (ft) }\end{array}$ & \\
\hline Massachusetts-Vermont State border & 0 & 490 & 565.9 & 571.6 & 5.7 \\
\hline DS from Broad Brook, Williamstown & 2,900 & 1,983 & 577.3 & 574.6 & -2.7 \\
\hline US from Broad Brook, Williamstown & 3,100 & 2,448 & 577.8 & 576.0 & -1.8 \\
\hline DS from Hemlock Brook, Williamstown & 7,800 & 7,255 & 583.4 & 583.9 & 0.5 \\
\hline US from Hemlock Brook, Williamstown & 8,000 & 8,312 & 583.6 & 585.0 & 1.4 \\
\hline DS from State Rt. 7/Simonds Rd., Williamstown & 10,400 & 10,216 & 587.0 & 587.0 & 0.0 \\
\hline US from State Rt. 7/Simonds Rd., Williamstown & 10,600 & 10,614 & 589.7 & 590.6 & 0.9 \\
\hline DS from Cole Ave., Williamstown & 16,900 & 16,586 & 598.3 & 596.5 & -1.8 \\
\hline US from Cole Ave., Williamstown & 17,050 & 16,942 & 600.7 & 599.1 & -1.6 \\
\hline DS from Green River, Williamstown & 19,000 & 18,738 & 604.9 & 603.8 & -1.1 \\
\hline US from Green River, Williamstown & 19,100 & 18,946 & 605.0 & 604.0 & -1.0 \\
\hline Williamstown and North Adams town border & 24,250 & 23,828 & 612.6 & 611.1 & -1.5 \\
\hline DS from Ashton Ave., North Adams & 26,450 & 25,960 & 617.7 & 616.9 & -0.8 \\
\hline US from Ashton Ave., North Adams & 26,550 & 26,272 & 617.9 & 619.2 & 1.3 \\
\hline DS from Barber Dam, North Adams & 29,450 & 28,976 & 623.4 & 622.8 & -0.6 \\
\hline $\begin{array}{l}\text { US from Barber Dam, North Adams } \\
\text { (USGS streamgage Hoosic River at Adams, } \\
\text { MA 01332500) }\end{array}$ & 29,750 & 29,232 & 628.9 & 630.3 & 1.4 \\
\hline DS from Protection Ave., North Adams & 32,050 & 31,483 & 632.5 & 633.1 & 0.6 \\
\hline US from Protection Ave., North Adams & 32,250 & 31,809 & 633.6 & 634.3 & 0.7 \\
\hline DS from State Rt. 2, North Adams & 33,000 & 32,324 & 634.6 & 634.7 & 0.1 \\
\hline US from State Rt. 2, North Adams & 33,100 & 32,659 & 634.6 & 635.2 & 0.6 \\
\hline
\end{tabular}


Table 7. Comparison of the water-surface elevations for the Hoosic River for the 1-percent annual exceedance probability discharge determined by Lombard and Bent (2015a) with those published in the effective Federal Emergency Management Agency flood insurance studies.-Continued

[Streamgage locations shown on figure 2 and described in table 1. FIS, flood insurance study; FEMA, Federal Emergency Management Agency; ft, foot; USACE, U.S. Army Corps of Engineers; HEC-RAS, Hydrologic Engineering Centers-River Analysis System; NAVD 88, North American Vertical Datum of 1988; DS, downstream; US, upstream; Rt., Route; Rd., Road; Ave., Avenue; USGS, U.S. Geological Survey; MA, Massachusetts; St., Street; NGVD 29, National Geodetic Vertical Datum of 1929]

\begin{tabular}{|c|c|c|c|c|c|}
\hline \multirow[t]{2}{*}{ Description of location } & $\begin{array}{l}\text { FIS, town of } \\
\text { Williamstown } \\
\text { (FEMA, 1983b) } \\
\text { and city of } \\
\text { North Adams, } \\
\text { Massachusetts } \\
\text { (FEMA, 1981) }\end{array}$ & $\begin{array}{l}\text { Lombard and } \\
\text { Bent (2015a) } \\
\text { USACE } \\
\text { HEC-RAS hy- } \\
\text { draulic model }\end{array}$ & $\begin{array}{l}\text { FIS, town of } \\
\text { Williamstown } \\
\text { (FEMA, 1983b) } \\
\text { and city of } \\
\text { North Adams } \\
\text { (FEMA, 1981) }\end{array}$ & $\begin{array}{c}\text { Lombard and } \\
\text { Bent (2015a) } \\
\text { USACE } \\
\text { HEC-RAS } \\
\text { hydraulic } \\
\text { model }\end{array}$ & \multirow{2}{*}{$\begin{array}{c}\text { Difference } \\
\text { between FIS } \\
\text { and Lombard } \\
\text { and Bent (2015a) } \\
\text { USACE HEC-RAS } \\
\text { hydraulic model } \\
\text { water-surface } \\
\text { elevation } \\
\text { (ft) }\end{array}$} \\
\hline & $\begin{array}{l}\text { Location from } \\
\text { Massachusetts- } \\
\text { Vermont State } \\
\text { border } \\
\text { (ft) }\end{array}$ & $\begin{array}{l}\text { Location from } \\
\text { Massachusetts- } \\
\text { Vermont State } \\
\text { border } \\
\text { (ft) }\end{array}$ & $\begin{array}{l}\text { Water-surface } \\
\text { elevation, } \\
\text { converted to } \\
\text { NAVD } 88 \\
\text { (ft) }\end{array}$ & $\begin{array}{l}\text { Water-surface } \\
\text { elevation, } \\
\text { NAVD } 88 \\
\text { (ft) }\end{array}$ & \\
\hline DS from State Rt. 2, North Adams & 37,450 & 37,108 & 643.9 & 651.1 & 7.2 \\
\hline US from State Rt. 2, North Adams & 37,700 & 37,550 & 651.0 & 651.9 & 0.9 \\
\hline US from Brown St., North Adams & 43,400 & 42,461 & 679.2 & 681.3 & 2.1 \\
\hline \multirow[t]{6}{*}{ DS from Brown St., North Adams } & 43,500 & 42,774 & 679.6 & 683.0 & 3.4 \\
\hline & & & \multicolumn{2}{|c|}{ Number of observations } & 26 \\
\hline & & & \multicolumn{2}{|c|}{ Minimum } & -2.7 \\
\hline & & & \multicolumn{2}{|l|}{ Maximum } & 7.2 \\
\hline & & & \multicolumn{2}{|l|}{ Average } & 0.7 \\
\hline & & & \multicolumn{2}{|l|}{ Median } & 0.6 \\
\hline
\end{tabular}

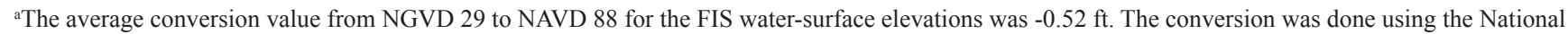
Geodetic Service VERTCON orthometric height conversion program (Gilbert, 1999) at http://www.ngs.noaa.gov/cgi-bin/VERTCON/vert_con.prl.

The differences in water-surface elevations between the recent (2015-16) hydraulic studies and the FISs likely are because of (1) improved land elevation data from lidar data collected in 2012, (2) detailed surveying of hydraulic structures and cross sections throughout the river reaches in 2012-13 (reflecting structure and cross section changes during the past 30 to 35 years), (3) updated hydrology analyses (3035 water years of additional peak flow data at streamgages), and (4) high-water marks from the 2011 tropical storm Irene flood being used for model calibration. These updated components used in the recent hydraulic models improved the simulated water-surface elevations for these river reaches. Additionally, the differences observed between the 1-percent AEP water-surface elevations for the recent studies and those in the FISs could be related to land-use changes - such as any increases in greater area of urban land uses because of increased medium- to high-density areas of residential housing, commercial and industrial development, and roads and highways in the river basins.

\section{Summary and Conclusions}

On August 28, 2011, intense rainfall of 3 to 10 inches that resulted from tropical storm Irene caused widespread flooding in western Massachusetts. August rainfall in western Massachusetts before tropical storm Irene had already saturated the ground, resulting in conditions prone to flooding. During a 9 to 18 hour period on August 28, 2011, the gage heights at all eight active U.S. Geological Survey streamgages in the Deerfield and Hoosic River Basins rose rapidly in response to the combination of saturated soils and intense rainfall. At Deerfield River near West Deerfield, Mass., 
streamgage (01170000), stage rose nearly 20 feet (ft) in less than 4 hours. On August 28, 2011, in the Deerfield and Hoosic River Basins in northwestern Massachusetts, new peaks of record were set at six of eight U.S. Geological Survey longterm streamgages with 46 to 100 years of record. Additionally, high-water marks were surveyed and indirect measurements of peak discharge were calculated at two discontinued streamgages in the Deerfield and Hoosic River Basins with 24 and 61 years of record, respectively. This data resulted in new historic peaks of record at the two discontinued streamgages from tropical storm Irene. In response to the tropical storm Irene flooding in western Massachusetts, a Presidential disaster declaration for Massachusetts was signed in September 2011. An interagency agreement between the Federal Emergency Management Agency and the U.S. Geological Survey was signed in April 2012 to update the hydrology and hydraulics of selected river reaches in the Deerfield and Hoosic River Basins in northwestern Massachusetts.

Peak flows that resulted from tropical storm Irene (August 28, 2011) were determined at the U.S. Geological Survey streamgages in the Deerfield and Hoosic River Basins by using stage-discharge rating curves and indirect computation methods. At the six streamgages in the Deerfield River Basin, peak flows from tropical storm Irene ranged from 1- to less than 0.2-percent annual exceedance probabilities (AEPs). At the four streamgages in the Hoosic River Basin, peak flows from Irene ranged from 5.4- to 0.4-percent AEPs. Generally, the AEPs were lowest at streamgages with river basins in the areas that had the higher rainfall amounts in northwestern Massachusetts.

The AEP discharges computed at streamgages for this study were compared with AEP discharges in the effective Federal Emergency Management Agency flood insurance studies (FISs) for communities in the study area, which were published in the late 1970s and early 1980s. Computed discharges for the 10-, 2-, 1-, and 0.2-percent AEPs at four streamgages (two on the main stem and two on tributaries to the Deerfield River) in the Deerfield River Basin, with 30 to 35 years of additional annual peak flow data, were generally higher than discharges in the FISs. The AEP discharges calculated for this study at two streamgages on the main stem of the Deerfield River ranged from about 3 percent lower to 14 percent higher than in the FISs. For the two streamgages on tributaries to the Deerfield River, estimated AEP discharges were considerably higher (from 27 to 89 percent) than in the FISs. For the four streamgages in the Hoosic River Basin, the 10-, 2-, 1-, and 0.2 -percent AEP discharges estimated generally ranged from 33 percent lower to 5 percent higher than in the FISs.

The 1-percent AEP discharge water-surface elevations (nonregulatory) simulated from the hydraulic models for the Deerfield, Green, and North Rivers in the Deerfield River Basin and the Hoosic River in the Hoosic River Basin were compared with those in the FISs. The differences in the 1-percent AEP discharge water-surface elevations for this study to those in the FISs varied throughout the river reaches; however, the average water-surface elevations for this study were higher than those in the FISs. At the selected locations on the Deerfield River, the 1-percent AEP discharge water-surface elevations ranged from $2.0 \mathrm{ft}$ lower to $7.3 \mathrm{ft}$ higher than water-surface elevations in the FISs, with average and median differences in water-surface elevations of 2.2 and $1.5 \mathrm{ft}$ higher, respectively. At the selected locations on the Green River, the 1-percent AEP discharge water-surface elevations ranged from $6.1 \mathrm{ft}$ lower to $6.1 \mathrm{ft}$ higher than in the FIS, with average and median differences in water-surface elevations of 2.3 and $2.4 \mathrm{ft}$ higher, respectively. At the selected locations on the North River, the 1-percent AEP discharge water-surface elevations ranged from $7.6 \mathrm{ft}$ lower to $3.7 \mathrm{ft}$ higher than in the FIS, with average and median differences in water-surface elevations of 0.3 and $1.7 \mathrm{ft}$ higher, respectively. At the selected locations on the Hoosic River, the 1-percent AEP discharge water-surface elevations ranged from $2.7 \mathrm{ft}$ lower to $7.2 \mathrm{ft}$ higher than in the FISs, with average and median differences in watersurface elevations of 0.7 and $0.6 \mathrm{ft}$ higher, respectively. The differences in water-surface elevations between the recent (2015-16) hydraulic studies and the FISs likely are because of (1) improved land elevation data from light detection and ranging (lidar) data collected in 2012, (2) detailed surveying of hydraulic structures and cross sections throughout the river reaches in 2012-13 (reflecting structure and cross section changes during the last 30-35 years), (3) updated hydrology analyses (30-35 water years of additional peak flow data at streamgages), and (4) high-water marks from the 2011 tropical storm Irene flood being used for model calibration. Additionally, the water-surface elevation differences could be related to land-use changes - such as any increases in area of urban land uses because of increased medium- to highdensity areas of residential housing, commercial and industrial development, and roads and highways in the river basins.

\section{References Cited}

Abel, David, 2011, Tired Irene slaps N.E.: Boston Globe, August 29, accessed December 5, 2014, at http://www. boston.com/news/local/massachusetts/articles/2011/08/29/ tired_irene_slaps_ne/?page $=$ full.

Avila, L.A., and Cangialosi, John, 2011, Tropical cyclone report, Hurricane Irene (AL092011), 21-28 August 2011: National Hurricane Center, 45 p., accessed July 20, 2015, at http://www.nhc.noaa.gov/data/tcr/AL092011_Irene.pdf.

Barry, Stephanie, 2011, Irene leaves renowned quilter Ann Brauer in search of new quilt shop: MassLive, August 31, accessed December 5, 2014, at http://www.masslive.com/ news/index.ssf/2011/08/irene_leaves_renowned_quilter_ ann_brauer_in.html. 
Benson, M.A., and Dalrymple, Tate, 1967, General field and office procedures for indirect discharge measurements: U.S. Geological Survey Techniques of Water-Resources Investigations, book 3, chap. A1, 30 p., accessed October 18, 2014, at http://pubs.usgs.gov/twri/twri3-a1/.

Bent, G.C., Lombard, P.J., and Dudley, R.W., 2015, Flood-inundation maps for the North River in Colrain, Charlemont, and Shelburne, Massachusetts, from the confluence of the East and West Branch North Rivers to the Deerfield River: U.S. Geological Survey Scientific Investigations Report 2015-5108, 16 p., appendixes, accessed December 5, 2015, http://dx.doi.org/10.3133/ sir20155108.

Bent, G.C., Medalie, Laura, and Nielsen, M.G., 2013, Highwater marks from tropical storm Irene for selected river reaches in northwestern Massachusetts, August 2011: U.S. Geological Survey Data Series 775, 13 p., accessed February 24, 2014, http://pubs.usgs.gov/ds/775/.

Bradley, D.N., 2012, Slope-area computation program graphical user interface 1.0-A preprocessing and postprocessing tool for estimating peak flood discharge using the slope-area method: U.S. Geological Survey Fact Sheet 2012-3112, 4 p., accessed October 18, 2014, at http://pubs.usgs.gov/ fs $/ 2012 / 3112$.

Cohn, T.A., Lane, W.M., and Baier, W.G., 1997, An algorithm for computing moments-based flood quantile estimates when historical flood information is available: Water Resources Research, v. 33, no. 9, p. 2089-2096.

Cohn, T.A., Lane, W.M., and Stedinger, J.R., 2001, Confidence intervals for expected moments algorithm flood quantile estimates: Water Resources Research, v. 37, no. 6, p. $1695-1706$.

Cohn, T.A., Berenbrock, Charles, Kiang, J.E., and Mason, R.R., 2012, Calculating weighted estimates of peak streamflow statistics: U.S. Geological Survey Fact Sheet 20123038, 4 p., accessed May 5, 2015, at http://pubs.usgs.gov/ fs $/ 2012 / 3038 /$.

Commonwealth of Massachusetts, 2016, Hudson River watershed: Massachusetts Executive Office of Energy and Environmental Affairs Web page, accessed February 12, 2016, at http://www.mass.gov/eea/waste-mgnt-recycling/ water-resources/preserving-water-resources/masswatersheds/hudson-river-watershed.html.

Dalrymple, Tate, and Benson, M.A., 1968, Measurement of peak discharge by the slope-area method: U.S. Geological Survey Techniques of Water-Resources Investigations, book 3, chap. A2, 12 p. [Also available at http://pubs.usgs. gov/twri/twri3-a2/.]
Deerfield River Watershed Association, 2005, Deerfield by the numbers-Watershed facts and figures: Deerfield River Watershed Association Web page, accessed April 12, 2013, at http://www.deerfieldriver.org/facts.html.

Denny, C.S., 1982, Geomorphology of New England: U.S. Geological Survey Professional Paper 1208, 18 p., 1 pl., accessed May 5, 2015, at http://pubs.er.usgs.gov/publication/pp1208.

Fanelli, C., and Fanelli, P., 2011, NOAA water level and meteorological data report-Hurricane Irene: U.S. Department of Commerce, National Oceanic and Atmospheric Administration, National Ocean Service Center for Operational Oceanographic Products and Services, accessed May 28, 2015, at http://tidesandcurrents. noaa.gov/publications/Hurricane_Irene_Water_Level_and_ Meteorological_Data_Report.pdf.

Federal Emergency Management Agency, 1979a, Flood insurance study, Town of Buckland, Massachusetts: Washington, D.C., Federal Emergency Management Agency, 19 p.

Federal Emergency Management Agency, 1979b, Flood insurance study, Town of Conway, Massachusetts: Washington, D.C., Federal Emergency Management Agency, 18 p.

Federal Emergency Management Agency, 1980a, Flood insurance study, Town of Charlemont, Massachusetts: Washington, D.C., Federal Emergency Management Agency, 17 p.

Federal Emergency Management Agency, 1980b, Flood insurance study, Town of Colrain, Massachusetts: Washington, D.C., Federal Emergency Management Agency, 18 p.

Federal Emergency Management Agency, 1980c, Flood insurance study, Town of Deerfield, Massachusetts: Washington, D.C., Federal Emergency Management Agency, 22 p.

Federal Emergency Management Agency, 1980d, Flood insurance study, Town of Greenfield, Massachusetts: Washington, D.C., Federal Emergency Management Agency, 23 p.

Federal Emergency Management Agency, 1980e, Flood insurance study, Town of Shelburne, Massachusetts: Washington, D.C., Federal Emergency Management Agency, 17 p.

Federal Emergency Management Agency, 1981, Flood insurance study, City of North Adams, Massachusetts: Washington, D.C., Federal Emergency Management Agency, 19 p.

Federal Emergency Management Agency, 1983a, Flood insurance study, Town of Adams, Massachusetts: Washington, D.C., Federal Emergency Management Agency, 21 p.

Federal Emergency Management Agency, 1983b, Flood insurance study, Town of Williamstown, Massachusetts: Washington, D.C., Federal Emergency Management Agency, $17 \mathrm{p}$. 
Federal Emergency Management Agency, 2015, Massachusetts Tropical Storm Irene (DR-4028): Federal Emergency Management Agency Web page, accessed July 7, 2015, at http://www.fema.gov/disaster/4028.

Flynn, Jack, 2012, Western Massachusetts gets a \$44.7 million bad-weather bailout from the federal government: MassLive, January 9, accessed December 5, 2014, at http://www.masslive.com/news/index.ssf/2012/01/western mass_gets_a_447_millio.html.

Flynn, R.H., Bent, G.C., and Lombard, P.J., 2016, Floodinundation maps for the Green River, in Colrain, Leyden, and Greenfield, Massachusetts, from the USGS streamgage 01170100 near Colrain to the Deerfield River: U.S. Geological Survey Scientific Investigations Report 2016-5107, 18 p., accessed August 2016 at http://dx.doi.org/10.3133/ $\operatorname{sir} 20165107$.

Fontaine, R.A., 1987, Flood of April 1987 in Maine, Massachusetts, and New Hampshire: U.S. Geological Survey Open-File Report 87-460, 35 p., accessed December 3, 2015, at http://pubs.er.usgs.gov/publication/ofr87460.

Gilbert, D.G., 1999, National Geodetic Survey (NGS) height conversion methodology: National Geodetic Survey Web page, accessed July 28, 2015, at http://www.ngs.noaa.gov/ TOOLS/Vertcon/vert_method.html.

Gilmore, Mark, Yazwinski, Chester, Jr., Stokarski, Gary, Jr., Wozniakewicz, Michael, Eaton, Harold, Jr., Ness, Carolyn, Barrett, Steve, Rose, Lynn, Barrett, Marti, Sloan, Peggy, Smith, P.A., Johnson, Gratchen, and Clary, Ryan, 2011, The town of Deerfield-2011 multi-hazard mitigation plan: Deerfield, Mass., Town of Deerfield, September, 133 p., appendixes, accessed December 5, 2014, at http://deerfieldma.us/Pages/Deerfield\%202011\%20 Multi-\%20Hazard\%20Mitigation\%20Plan_FINAL\%20 REVIEW\%20D.pdf.

Graham, George, 2011, Shutdown of Greenfield's wastewater treatment plant sending wastewater into Deerfield and Connecticut Rivers: MassLive, August 30, accessed December 5, 2014, at http://www.masslive.com/news/index. ssf/2011/08/shutdown_of_greenfields_wastew.html.

Griffis, V.W., Stedinger, J.R., and Cohn, T.A., 2004, Log Pearson type 3 quantile estimators with regional skew information and low outlier adjustments: Water Resources Research, v. 40, W07503, 17 p.

Grover, N.C., 1937a, The floods of March 1936, part 1, New England rivers: U.S. Geological Survey Water-Supply Paper 798, 466 p., accessed December 3, 2015, at http://pubs. er.usgs.gov/publication/wsp798.

Grover, N.C., 1937b, The floods of March 1936, part 2, Hudson River to Susquehanna River region: U.S. Geological Survey Water-Supply Paper 798, 380 p., accessed December 3, 2015, at http://pubs.er.usgs.gov/publication/wsp799.
Horton, R.E., 1907, Weir experiments, coefficients, and formulas: U.S. Geological Survey Water-Supply and Irrigation Paper 200 (revision of Water-Supply and Irrigation Paper 150), 195 p., accessed June 10, 2015, at http://pubs.er.usgs. gov/publication/wsp200.

Hulsing, Harry, 1967, Measurement of peak discharge at dams by indirect methods: U.S. Geological Survey Techniques of Water-Resources Investigations, book 3, chap. A5, 29 p., accessed June 10, 2015, at http://pubs.usgs.gov/twri/twri3a5/.

Johnson, Patrick, 2011, Updated list of road closures in western Massachusetts due to Irene: MassLive, August 30, accessed December 5, 2014, at http://www.masslive.com/ news/index.ssf/2011/08/updated_list_of_road_closures. html.

Kinney, Jim, 2011a, Tropical storm Irene reported to have resulted in more than $\$ 90$ million in western Massachusetts insurance claims: MassLive, September 29, accessed December 5, 2014, at http://www.masslive.com/news/index. ssf/2011/09/tropical_storm_irene_reported.html.

Kinney, Jim, 2011b, Hurricane Irene deluges western Massachusetts; flood waters won't crest for days: MassLive, August 29, accessed December 5, 2014, at http://www. masslive.com/news/index.ssf/2011/08/tropical_storm irene_deluges_a.html.

Kinnison, H.B., 1930, The New England flood of November 1927: U.S. Geological Survey Water-Supply Paper 636, chapter C, p. 45-100, accessed December 10, 2015, at http://pubs.er.usgs.gov/publication/wsp636C.

Lombard, P.J., and Bent, G.C., 2015a, Flood-inundation maps for the Hoosic River, North Adams and Williamstown, Massachusetts, from the confluence with the North Branch Hoosic River to the Vermont state line: U.S. Geological Survey Scientific Investigations Report 2014-5236, 16 p., appendixes, accessed December 1, 2015, at http://dx.doi. org/10.3133/sir20145236.

Lombard, P.J., and Bent, G.C., 2015b, Flood-inundation maps for the Deerfield River, Franklin County, Massachusetts, from the confluence with the Cold River tributary to the Connecticut River: U.S. Geological Survey Scientific Investigations Report 2015-5104, 22 p., appendixes, accessed December 1, 2015, at http://dx.doi.org/10.3133/ sir20155104.

Lubchenco, Jane, and Furgione, Laura, 2012, Service assessment-Hurricane Irene, August 21-30, 2011: National Oceanic and Atmospheric Administration, 129 p., accessed July 20, 2015, at http://www.nws.noaa.gov/om/assessments/ pdfs/Irene2012.pdf. 
Mabee, S.B., Woodruff, J.D., Fellows, John, and Kopera, J.P., 2013, Landslides from tropical storm Irene in the Deerfield watershed, western Massachusetts [abs.]: Geological Society of America, Northeastern Section - 48th Annual Meeting, March 18-20, 2013, Bretton Woods, New Hampshire.

Massachusetts Department of Conservation and Recreation, 2011, Monthly precipitation composite: Massachusetts Executive Office of Energy and Environmental Affairs Web page, accessed February 12, 2016, at http://www.mass.gov/ eea/agencies/dcr/water-res-protection/water-data-tracking/ rainfall-program.html.

Massachusetts Department of Transportation, 2011a, MassDOT grants-Tropical storm Irene repairs: MassDOT Blog, accessed July 7, 2015, at http://blog.mass.gov/transportation/massdot-highway/massdot-grants-tropical-storm-irenerepairs/.

Massachusetts Department of Transportation, 2011b, MassDOT Secretary - Route 2 reopens: Road to Reform newsletter, December 16, accessed July 7, 2015, at https://www. massdot.state.ma.us/InformationCenter/WeeklyNewsletters/ RoadtoReformNewsletter12162011.aspx.

Massachusetts Department of Transportation, 2012a, Route 2 reconstruction named "project of the year": MassDOT Blog, accessed July 7, 2015, at http://blog.mass.gov/transportation/massdot-highway/route-2-reconstruction-named-project-of-the-year/.

Massachusetts Department of Transportation, 2012b, MassDOT announces reimbursement for western Massachusetts communities for storm roadway repairs: Massachusetts Department of Transportation Web page, accessed July 7 , 2015, at https://www.massdot.state.ma.us/desktopmodules/ advancedarticles/articledetail.aspx?itemid=152\&moduleid= 1030\&tabid $=367 \&$ portalid $=0$.

Massachusetts Emergency Management Agency, 2011, State Emergency Operations Center, Hurricane Irene situation report \#2: Massachusetts Emergency Management Agency, 11 p., accessed December 5, 2014, at http://www. massleague.org/Programs/EmergencyPreparedness/IreneMEMAsitrep-08-29-2011.pdf.

Massachusetts Geodetic Survey, 1936, High water data flood of March 1936 in Massachusetts, 210 p.

Massachusetts Geodetic Survey, 1939, High water data floods of March 1936 and September 1938 in Massachusetts, $129 \mathrm{p}$.

Massachusetts Office of Geographic Information System, 2015, MassGIS data - LiDAR terrain data: Massachusetts Executive Office of Energy and Environmental Affairs Web page, accessed July 20, 2015, at http://www.mass.gov/anf/ research-and-tech/it-serv-and-support/application-serv/ office-of-geographic-information-massgis/datalayers/lidar. html.
Matthai, H.F., 1967, Measurement of peak discharge at width contractions by indirect methods: U.S. Geological Survey Techniques of Water-Resources Investigations, book 3, chap. A4, 44 p., accessed October 18, 2014, at http://pubs. usgs.gov/twri/twri3-a4/.

McCallum, B.E., Painter, J.A., and Frantz, E.R., 2012, Monitoring inland storm tide and flooding from Hurricane Irene along the Atlantic Coast of the United States, August 2011: U.S. Geological Survey Open-File Report 2012-1022, 28 p., accessed June 11, 2015, at http://pubs.usgs.gov/ of $/ 2012 / 1022 /$.

Murphy, David, 2013, Process for soliciting, selecting, and developing mitigation projects part II-Repeating the process after a disaster: Association of State Floodplain Managers Conference, Hartford, Conn., June 12, 2013, 50 p., accessed December 5, 2014, at http://www.floods.org/ Files/Conf2013_ppts/D4/D4_Murphy.pdf.

National Oceanic and Atmospheric Administration, 2011, NWS Taunton, Massachusetts-Significant weather event: National Oceanic and Atmospheric Administration Web page, accessed March 11, 2013, at http://www. erh.noaa.gov/box/displayEvent.php?event=Aug_2728_2011\&element=pcpn.

National Oceanic and Atmospheric Administration, 2013, 2012 FEMA topographic lidar-Hudson-Hoosic and Deerfield watersheds: National Oceanic and Atmospheric Administration metadata, accessed June 11, 2015, at http://coast.noaa.gov/htdata/lidar1_z/geoid12a/data/2556/ ma2012_fema_deerfield_metadata.html.

National Oceanic and Atmospheric Administration, National Centers for Environmental Information, 2016a, Data tools1981-2010 normals: National Oceanic and Atmospheric Administration Web page, accessed February 12, 2016, at https://www.ncdc.noaa.gov/cdo-web/datatools/normals.

National Oceanic and Atmospheric Administration, National Centers for Environmental Information, 2016b, National temperature and precipitation maps, August 2011 statewide ranks: National Oceanic and Atmospheric Administration Web page, accessed February 12, 2016, at https://www. ncdc.noaa.gov/temp-and-precip/us-maps/1/201108?products []=statewidepcpnrank.

National Weather Service, 2005a, Rainfall totals 10/07-09/05 flood event: National Weather Service Web page, accessed July 28, 2015, at http://www.weather.gov/images/aly/Past_ Events/2005/Oct_7-9_2005_Tammy_Rainfall.jpg.

National Weather Service, 2005b, Major floods, Albany, New York: National Weather Service Web page, accessed July 28, 2015, at http://www.weather.gov/aly/MajorFloods. 
National Weather Service, 2011, Taunton, Massachusetts, August 30, 2011: National Weather Service public information statement, spotter report, accessed February 12, 2013, at http://www.erh.noaa.gov/box/displayEvent. php?event=Aug_27-28_2011\&element=pcpn.

Olson, S.A., 2014, Estimation of flood discharges at selected annual exceedance probabilities for unregulated, rural streams in Vermont, with a section on Vermont regional skew regression, by Veilleux, A.G.: U.S. Geological Survey Scientific Investigations Report 2014-5078, 27 p., appendices, accessed June 1, 2015, at http://dx.doi.org/10.3133/ sir20145078.

Olson, S.A., and Bent, G.C., 2013, Annual exceedance probabilities of the peak discharges of 2011 at streamgages in Vermont and selected streamgages in New Hampshire, western Massachusetts, and northeastern New York: U.S. Geological Survey Scientific Investigations Report 2013-5187, 17 p., accessed June 1, 2015, at http://dx.doi. org/10.3133/sir20135187.

Paulsen, C.G., 1940, Hurricane floods of September 1938: U.S. Geological Survey Water-Supply Paper 867, 562 p., accessed December 3, 2015, at http://pubs.er.usgs.gov/publication/wsp867.

Republican Newsroom, The, 2011, Massachusetts state police-I-91 over Deerfield River could be closed for days after Hurricane Irene: MassLive, August 28, accessed December 5, 2014, at http://www.masslive.com/news/index. ssf/2011/08/massachusetts_state_police_i-9.html.

Schworm, Peter, and Lutz, Jaime, 2011, Flooding, outages stay as reminders of storm's wrath: Boston Globe, August 31, accessed December 5, 2014, at http://www.boston.com/ news/local/massachusetts/articles/2011/08/31/flooding_outages_stay_as_reminders_of_storms_wrath/.
Stabile, Lori, 2011, Damage from tropical storm Irene still being assessed in Franklin and Berkshire counties: MassLive, September 3, accessed December 5, 2014, at http://www.masslive.com/news/index.ssf/2011/09/damage_from_tropical_storm_ire.html.

Suro, T.P., Roland, M.A., and Kiah, R.G., 2016, Flooding in the northeastern United States, 2011: U.S. Geological Survey Professional Paper 1821, 32 p., accessed January 25, 2016, at http://pubs.er.usgs.gov/publication/pp1821.

U.S. Geological Survey, 1952, New Year flood of 1949 in New York and New England: U.S. Geological Survey Circular 155, 109 p., accessed December 3, 2015, at http://pubs. er.usgs.gov/publication/cir155.

U.S. Geological Survey, 2012a, Annual water data reports: U.S. Geological Survey Web page, accessed July 22, 2015, at http://wdr.water.usgs.gov/.

U.S. Geological Survey, 2012b, Office of surface water technical memorandum 2013.01 - Computation of annual exceedance probability (AEP) for characterization of observed flood peaks, accessed July 28, 2015, at http://water.usgs.gov/admin/memo/SW/sw13.01.pdf.

U.S. Geological Survey, 2014, Peak streamflow for the nation: U.S. Geological Survey National Water Information System Web interface, accessed May 31, 2014, at http:/nwis.waterdata.usgs.gov/nwis/peak.

Veilleux, A.G., Cohn, T.A., Flynn, K.M., Mason, R.R., Jr., and Hummel, P.R., 2014, Estimating the magnitude and frequency of floods using the PeakFQ 7.0 program: U.S. Geological Survey Fact Sheet 2013-3108, 2 p., accessed July 1, 2015, at http://pubs.usgs.gov/fs/2013/3108/. 
For more information concerning this report, contact: Director, New England Water Science Center U.S. Geological Survey 10 Bearfoot Road Northborough, MA 01532

dc_nweng@usgs.gov or visit our Web site at: http://newengland.water.usgs.gov

Publishing support by:

The Pembroke and Rolla Publishing Service Centers 


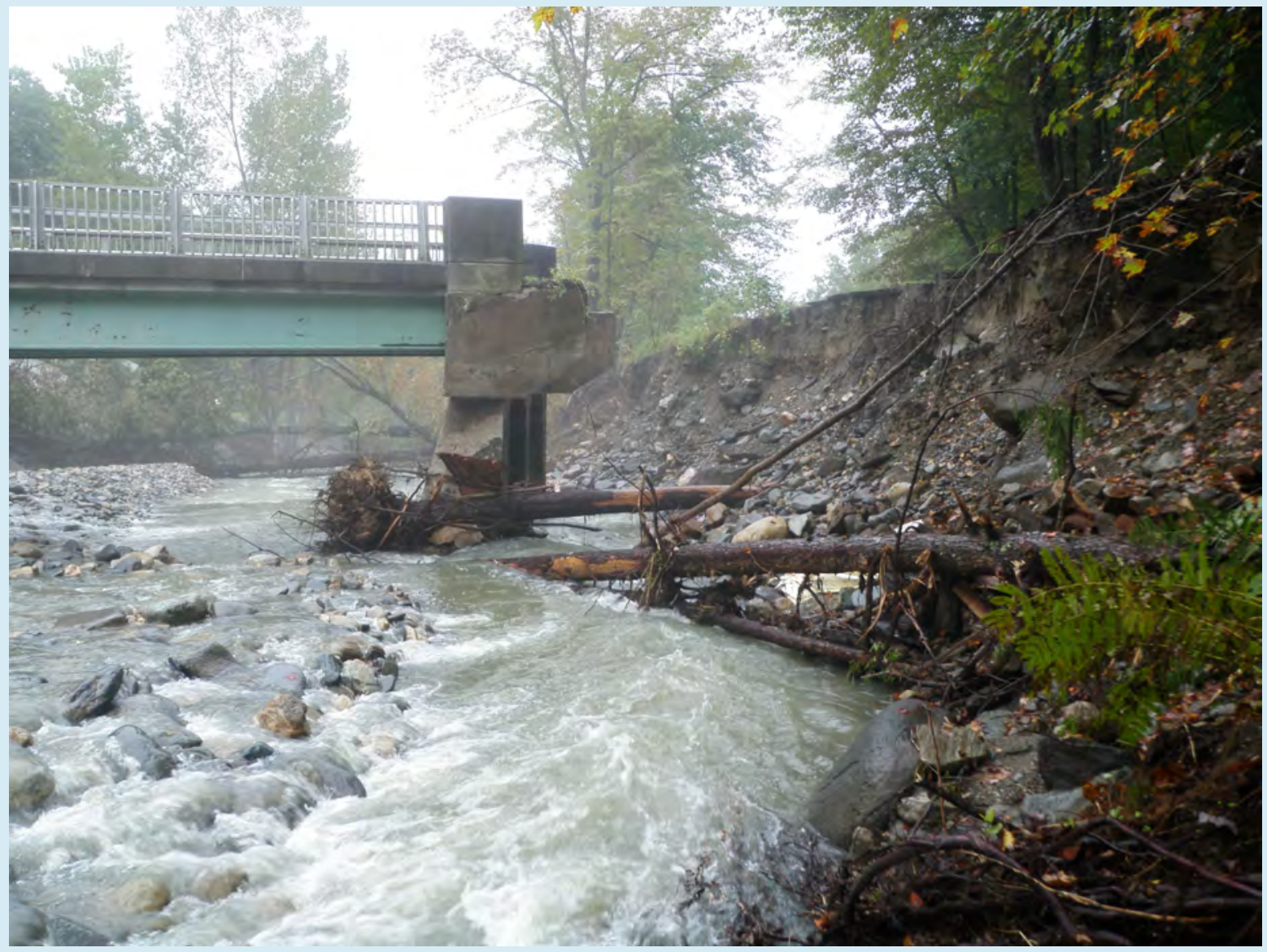

